
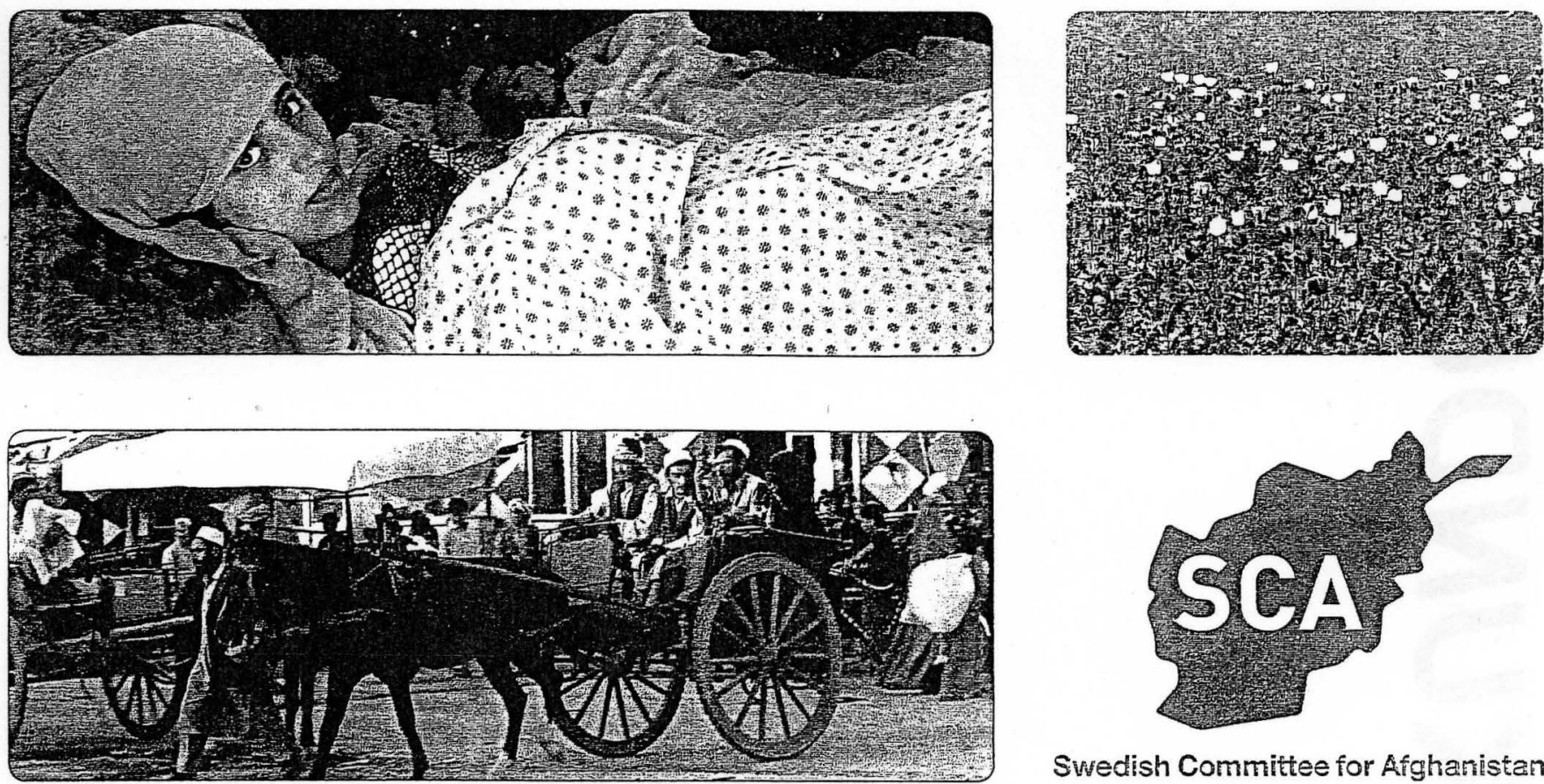

Swedish Committee for Afghamistan
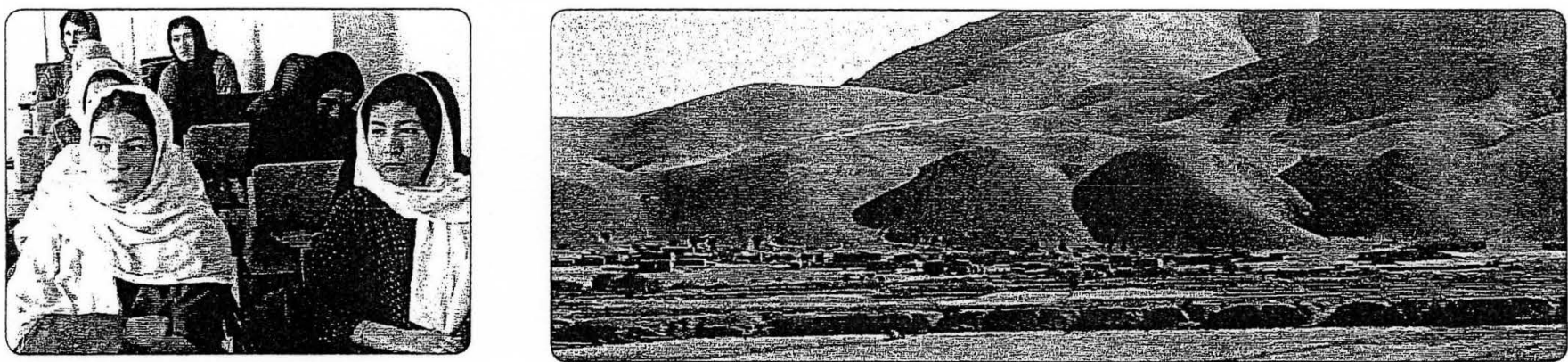

\title{
Provincial Survey
} of

\section{KUNDUZ}
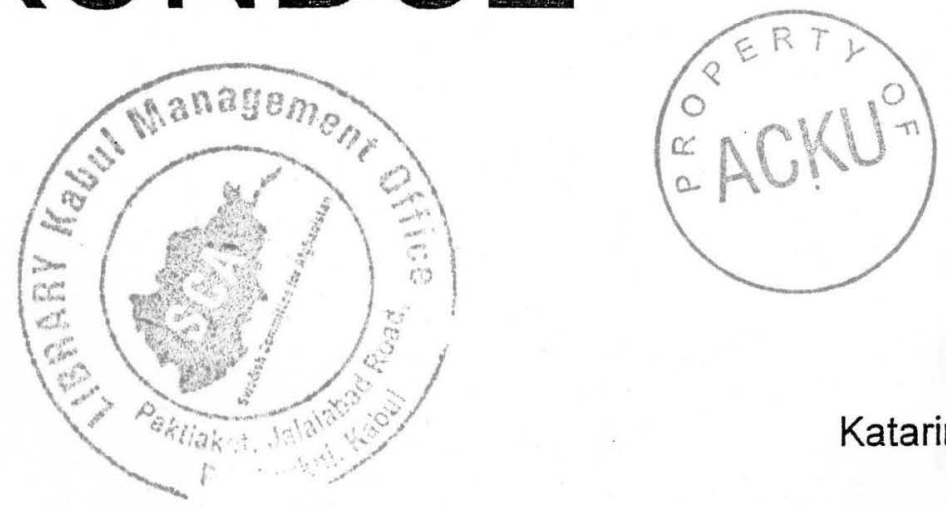

Katarina Larsson Consultant 


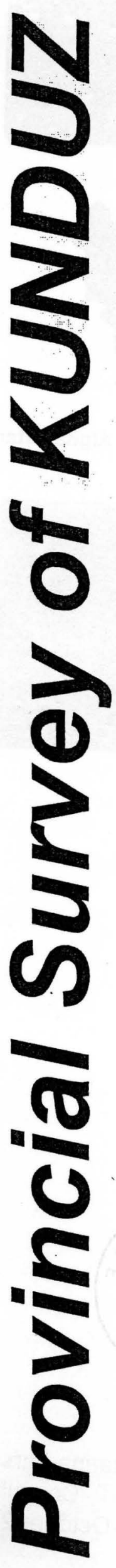

Katarina Larsson Consultant October 2004 


\section{Preface}

As the Swedish Committee for Afghanistan (SCA) embarked upon two new national strategies, the Basic Package of Health Service (BPHS) in Kunduz and Wardak provinces, and the National Solidarity Programmes (NSP) in Wardak, a certain geographical focusing emerged compared to our previous presence in 21 of the 34 provinces of Afghanistan. Historically, much of the four major programmes of SCA (health, education, disability and agriculture) has been implemented on a needs base without a coherent strategic model for the future. In the new Afghan environment, the new strategies express concerted efforts between authorities, donors and implementers. The new strategies also open up for dismantling of old ones, as other actors take over where SCA used to operate. This trend is envisaged to continue in the near future, as national authorities may take an increasing responsibility for service delivery.

The emerging geographical concentration calls for more profound insight, knowledge and information about regions where we are to work in the coming years. Socioeconomic conditions and livelihoods, demography, topography, governance and power-holding, services available and infrastructure are some conditions that make up pre-conditions and framework, together with inputs by other actors, agencies, donors and the Afghan authorities.

To that end, SCA asked Katarina Larsson to produce comprehensive provincial surveys on Kunduz and Wardak. It is a pleasure to see the requested products completed and ready for dissemination. They offer interesting reading for SCA board and staff members and others involved in the two provinces.

The author has taken great care to make sure that facts are correct with thorough scrutiny of data, often cross-checked by SCA staff members, to the extent possible. However, the surveys are the responsibility of the author alone and do not necessarily reflect views and opinions of SCA.

I would like to express beyond the contractua commitment to SCA reviews offers comp efforts of SCA to cr Afghanistan.

Stockholm Decer

Bengt Kristian: Secretary Gen

\author{
-are thanks to Katarina Larsson for her work that goes \\ - asiltant. It comprises a large proportion of \\ $\rightarrow$ s reading of the provincial \\ -orts relevant for the \\ ment in
}


"Yet the people of Afghanistan are not on the brink of starvation, nor have they been in recent history, due mainly to widespread personal and private initiative. Afghans are a resourceful, resilient, creative, opportunity-seeking, and entrepreneurial people (as witnessed by the high incidence of labour migration, entrepreneurial activity wherever they are located, trading networks, and remittances). Their achievements in the face of adversity are noteworthy."

From "Afghanistan: State Building, Sustaining Growth, and Reducing Poverty. A Country Economic Report," The World Bank, 2004 


\section{CONTENTS}

Food for Thought

Acronyms, Currency, Fiscal Year

Map of Kunduz

1. Introduction and Methods

2. Background and Summary: Kunduz Province

3. Warlords and Other Power Holders

4. The Security Situation for NGOs

5. Women and Human Rights

6. The Opium Economy

7. Agriculture

8. Primary and Secondary Education

9. Health

10. Disability

\section{APPENDICES}

I. Terms of Reference

II. Maps of Reconstruction and Development Projects in Kunduz, August 2004

II.1 Agriculture Projects

II.2 Community development projects

II.3 Education projects

II.4 Food aid projects

II.5 Health projects

II.6 In frastructure projects

II.7 Irrigation projects

II.8 Shelter and housing projects

II.9 Water and sanitation projects

III. References

IV. List of Contacts 


\title{
ACRONYMS, CURRENCY AND FISCAL YEAR
}


IWPR Institute for War and Peace Reporting

KfW Kreditanstalt für Wiederaufbau (German Development Bank)

KRA Kunduz Rehabilitation Agency

LSE London School of Economics and Political Science

MCI Mercy Corps International

MISFA Microfinance Investment and Support Facility for Afghanistan

MRRD Ministry of Rehabilitation and Rural Development

MSF Médicins Sans Frontières/Doctors Without Borders

MSH Management Sciences for Health

NGO Non-Governmental Organisation

NRVA National Risk and Vulnerability Assessment

NSP National Solidarity Programme

PRT Provincial Reconstruction Team

RAD Rehabilitation of Afghans with Disability

RAMP Rebuilding Agricultural Markets Programme (USAID)

RBM Roll Back Malaria Programme

REFS Rehabilitation of Economic Facilities and Services (USAID)

SCA Swedish Committee for Afghanistan

SFL Shelter for Life

Sida Swedish International Development Cooperation Agency

UNAMA United Nations Assistance Mission to Afghanistan

UNDP United Nations Development Programme

UNFPA United Nations Population Fund (also written UNPF)

UNHCR United Nations High Commissioner for Refugees

UNICEF United Nations Children's Fund

UNODC United Nations Office on Drugs and Crime

UNOPS United Nations Office for Project Services

USAID United States Agency for International Development

WFP World Food Programme

WHO World Health Organisation

CURRENCY EQUIVALENT

Currency Unit = Afghani (Afs)

US $\$ 1=49$ Afs (2004 Average)

GOVERNMENT FISCAL YEAR

21 March -20 March

$2001 / 02=1380$

$2002 / 03=1381$

$2003 / 04=1382$

$2004 / 05=1383$ 


\section{Kunduz}
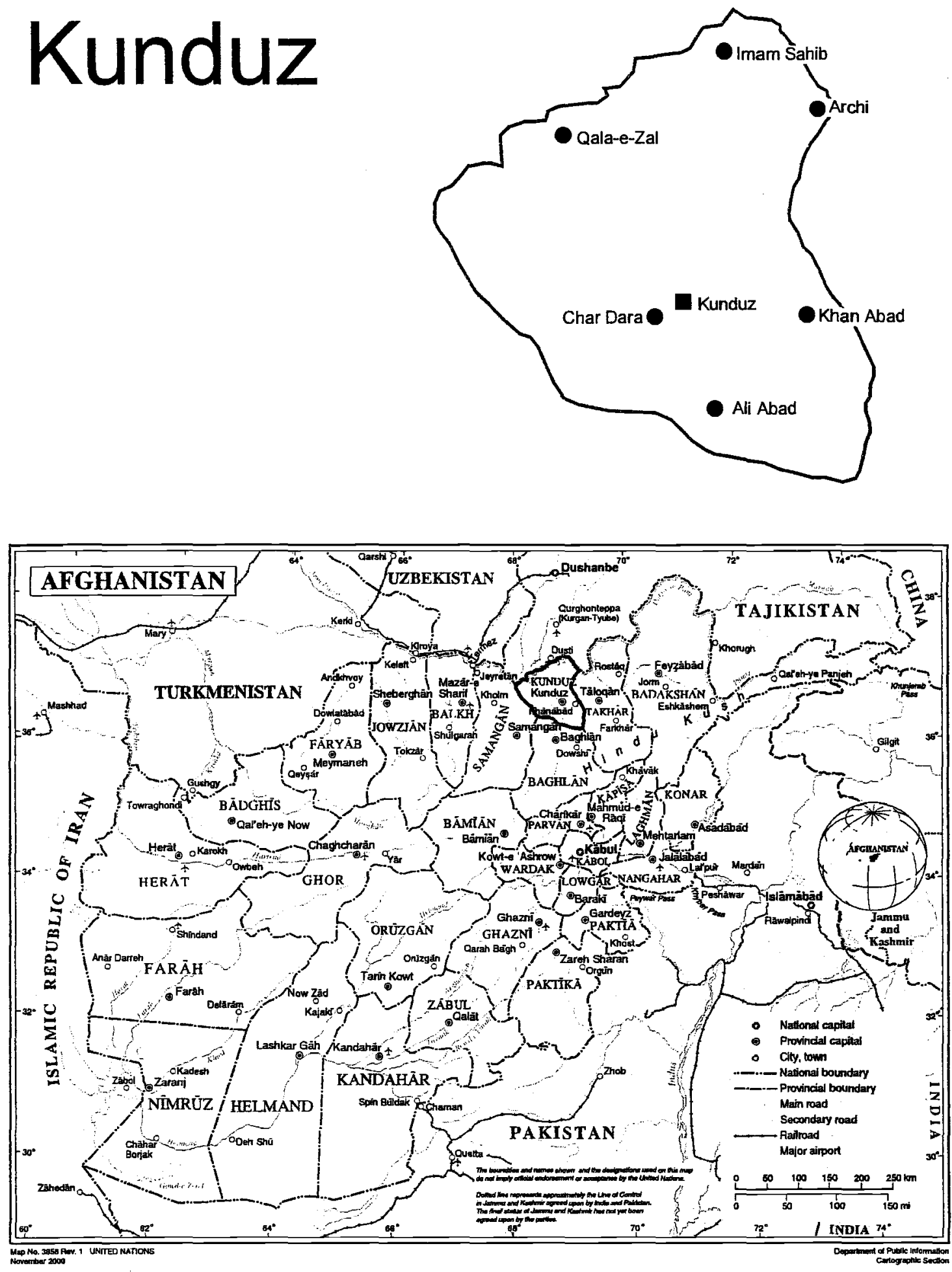


\section{INTRODUCTION AND METHODS}

The Swedish Committee for Afghanistan (SCA) has been awarded a contract by the Ministry of Health to implement the Basic Package of Health Services (BPHS) in the province of Kunduz. This, in fact, means that SCA now has the responsibility for the implementation of all health care in the province. In addition, SCA gives substantial support to primary and secondary education, services for the disabled and agriculture in the province. To provide the SCA Board, management, and middle-level staff with an updated and broad picture of the current development situation in Kunduz, I was asked to prepare a provincial survey. My Terms of Reference are presented in Appendix I. In total, I was given four weeks to prepare the survey.

Basically, the survey is a desk study. Sources of information are presented in Appendix III. References. Documents of especially great value for the survey have been Out of Step? Agricultural Policy and Afghan Livelihoods by Ian Christoplos, AREU, as well as Afghanistan: State Building, Sustaining Growth, and Reducing Poverty. A Country Economic Report and A Guide to Government in Afghanistan, both published by The World Bank, the latter publication in partnership with AREU. In addition, a large number of smaller articles and news items from the web are quoted, with reference given in the text.

The survey is also based on meetings I had in Afghanistan from 27 May to 8 June 2004. I interviewed SCA staff, government staff, local officials, UN/World Bank/EC and NGO representatives, and ordinary women and men. Most of my time was spent in Kabul. I visited Kunduz on 2-3 June and returned to Kabul by car on 3-4 June. See Appendix IV. List of Contacts.

The information on population by district, gender and age are based on official but preliminary data I received from the Director General of the Central Statistics Office (CSO) in Kabul. In the absence of a real census and other reliable sources of information, the figures in this survey should be seen as rough estimates of limited reliability.

In early 2004, SCA conducted some 35 focus group discussions on health with men, and interviewed 500 women through a questionnaire regarding living conditions and health, including reproductive health, in Kunduz. The questionnaires and the results of the focus group discussions are still being processed. The report from that socio-economic study, with emphasis on health, will be an important supplement to my provincial survey.

Many people have been helpful in providing data for this survey. In particular, I would like to thank Mr Anayatullah, Information Chief Officer, SCA, for arranging my meetings in Afghanistan, as well as Mr Sergiy Illarionov, UNAMA Director in Kunduz, and Mr Borje Almqvist, journalist, for providing valuable information. I am also grateful for useful and inspiring comments on the first draft of this survey from Dr Bengt Kristiansson, Secretary General of SCA. 


\section{BACKGROUND AND SUMMARY: KUNDUZ PROVINCE}

Area:
Area - comparative:

Land boundaries:

Climate:

Natural hazards:

Terrain:

Elevation extremes:

Major rivers:
8,040 square kilometres (AIMS* 2004). See Appendix II. Maps. Afghanistan covers 647,500 sq.km.; Sweden 450,000 sq.km. Wardak covers 8,938 sq.km.; Kandahar 54,022 sq.km.; Herat 54,775 sq.km.; and Södermanland 8,388 sq.km.

International: Tajikistan

National: Takhar, Baghlan, Samangan and Balkh provinces, clockwise.

Arid to semiarid. Hot summers and cold winters. During 2003-04, SCA employees in Kunduz City have recorded $+49^{\circ}$ as maximum temperature, and $-11^{\circ}$ as minimum temperature.

Drought, local flooding and frost attacks. Other hazards are sandstorms, earthquakes, and locust attacks.

Fertile valleys, semiarid lands and deserts.

Lowest point: 258 metres above sea level at the Amu Darya. Highest point: 1,321 metres above sea level in Imam Sahib. The Amu Darya River, the Kunduz River and the Pyandzh River.

\section{Population by district, gender and age:}

\begin{tabular}{|c|c|c|c|c|c|}
\hline & Males & Females & Total & Sex ratio & Under 18 yrs \\
\hline Ali Abad & 19,275 & 19,247 & 38,522 & 100.1 & $61.4 \%$ \\
\hline Char Dara & 30,963 & 30,624 & 61,587 & 101.1 & $58.6 \%$ \\
\hline Dasht-e-Archi & 28,461 & 28,689 & 57,150 & 99.2 & $57.7 \%$ \\
\hline Imam Sahib & 100,707 & 98,479 & 199,186 & 102.3 & $57.6 \%$ \\
\hline Khan Abad & 56,780 & 57,964 & 114,744 & 98.0 & $60.1 \%$ \\
\hline Kunduz District & 123,497 & 123,200 & 246,697 & 100.2 & $57.7 \%$ \\
\hline Qala-e-Zal & 27,716 & 27,033 & 54,749 & 102.5 & $55.0 \%$ \\
\hline Kunduz, Total & 387,399 & 385,236 & 772,635 & 100.6 & $58.1 \%$ \\
\hline
\end{tabular}

Note: The above table is based on official data from the first phase of the A fghan population census (2004) for Kunduz. The latest data available were received from Mr Mohd Ali Watanyar, Director General of the Central Statistics Office (CSO) in June 2004. In the absence of a real census or other reliable sources of information, the figures above are rough estimates of limited reliability.

Provincial capital: $\quad$ Kunduz City (latitude: $36.40 \mathrm{~N}$, same latitude as Gibraltar, longitude: $068.55 \mathrm{E}$, altitude: $433 \mathrm{~m}$ ) is the fifth largest population centre in Afghanistan. It is the only large town in the north of Afghanistan with a sizeable Pashtun population. Kunduz City was the last northern Taliban stronghold to withstand the US-backed offensive in 2001. At present, it is one of the most peaceful provincial capitals in Afghanistan. According to the Ministry of Urban Planning, Kunduz City has some 200,000 inhabitants, with a large influx of IDPs and returnees. The city is experiencing an economic boom in 2004. The distance from Kabul to Kunduz by air is 236 kilometres. By car, the trip nonstop took 12 hours in

\footnotetext{
- AIMS (Afghanistan Information Management System) of UNDP produces standard and custom geographic information systems (GIS), and provides technical assistance to organisations on design of databases and GIS systems. AIMS is based in Kabul, with regional representation in the UNAMA offices. AIMS datasets and maps are free of charge through its web site (www.aims.org.af)
} 
June 2004. When the Salang Pass is closed, the delays can be considerable.

Rural - urban, by district: Only Kunduz District (Markaz Kunduz) could be classified as partly urban.

Population density: Kunduz, Khan Abad and Imam Sahib are the most densely populated districts. Qala-e-Zal is mostly desert, and sparsely populated. For population density, see Appendix II. Maps.

Roads:

Roads, including the Tajikistan border - Kunduz - Pul-e-Khumri highway, are in bad shape. The World Bank/IDA is funding the rehabilitation of the Kunduz - Pul-e-Khumri highway, including work on the Salang tunnel, and the Kunduz - Faizabad road. USAID is up-grading and rehabilitating long distances of secondary roads in the province to facilitate agricultural market access.

Airfield: $\quad$ The airfield of Kunduz City has a two-km runway. In June 2004, the Asian Development Bank (ADB) announced that it will fund an up-grading of the Kunduz Airfield in 2005. In the meantime, the German PRT handles maintenance.

Warlords and other power holders: The most powerful man in Kunduz is General Mohammad Daoud, followed by Commander Mir Alam and many local commanders. The Provincial Governor is Engineer Mohammad Omar Khan. See Chapter 3. Warlords and Other Power Holders.

Security for NGOs: According to the Afghanistan Non-Governmental Organisations Security Office (ANSO), the security situation is relatively calm. Germany runs a Provincial Reconstruction Team (PRT) in Kunduz. As of September 2004, it was staffed by 270 peacekeeping troops from the NATO-led International Security Assistance Force (ISAF) in Kabul and some 30 civilians. See Chapter 4. The Security Situation for NGOs.

Women and human rights: Women's fundamental human rights are denied. Violence against women is a cause of immense suffering. Strong social and cultural norms continue to limit women's public role. See Chapter 5. Women and Human Rights.

Ethnic groups: Kunduz province is often described as one of the most multi-ethnic provinces in Afghanistan. According to UNHCR (2002), the ethnic composition per district was as follows in 2002:

Ali Abad: Pashtuns 47\%, Tajiks 45\%, Hazara 20\%, Uzbek 18\% [ $=130 \%$ !]

Char Dara: Pashtuns 40\%, Uzbeks 35\%, Tajik 15\%, Turkmens $10 \%$ Dasht-e-Archi: Pashtuns 55\%, Tajiks 25\%, Uzbeks 12\%, Turkmens $8 \%$ Imam Sahib: Uzbek $45 \%$, Pashtuns $25 \%$, Tajiks $25 \%$, Turkmens $5 \%$, Hazara $1 \%$

Khan Abad: Pashtuns 40\%, Tajiks 25\%, Hazara 20\%, Uzbek 10\%, Pashai 5\% Kunduz district: no data available Qala-e-Zal: Turkmens $90 \%$ and Pashtuns $10 \%$

Under the Taliban regime, predominantly Pashtun, there were atrocious human rights abuses against the Hazaras. Ethnic revenge attacks have been reported. Land use conflict, as well as property and water rights conflicts, with an ethnic dimension are common.

Religion: The vast majority are Sunni Muslims. Of the Hazaras, the vast majority are Shi'a Muslims (a small minority of Hazaras are Sunni Muslims). There are Ismaili populations in Ali Abad and in a 
Languages:

Food insecurity:

Opium:

Agriculture: village cluster called Nekpai (Personal communication, AKF, November 2004). In addition, there are Sufi groups in Kunduz. Dari, Pashtu, Turkic languages, mainly Uzbek and Turkmen, Pashai, Gujuri and other minor languages. Many men are bilingual.

Of the 34 provinces in Afghanistan, Kunduz is the only province which shows $0 \%$ food insecurity (estimated percentage of population getting less than $2,100 \mathrm{kcal}$ per capita daily) in the National Risk and Vulnerability Assessment (NRVA) for 2004. The national food insecurity average per province for 2004 is 37 percent. See Chapter 7. Agriculture.

Opium production in Kunduz is increasing substantially, and flourishing. Reportedly the provincial leadership, including the police, is benefiting greatly with impunity. Also the poor are benefiting. See Chapter 6 . The Opium Economy.

Kunduz is one of Afghanistan's major farming provinces, with high potential for increased and diversified production for export. A significant cereal surplus is produced. In 2003, some wheat and rice were not even harvested due to sinking prices and labour shortage. Opium production was many times more profitable. See Appendix II. Map of Agricultural Projects, and Chapter 7. Agriculture.

Main sources of income: Opium, agriculture and remittances from male family members working in other parts of Afghanistan, Iran, Pakistan and the Gulf states. Carpet weaving and embroidery for Turkmen women and girls.

Refugees and IDPs: According to UNHCR, the return by ethnicity from Pakistan (1 March 2002 - 30 April 2004) and Iran (9 April 2002 - 30 April 2004) under the Assisted Voluntary Repatriation Programme was as follows:

Ali Abad
Char Dara
Dasht-e-Archi
Imam Sahib
Khan Abad
Kunduz
Qalay-I-Zal

Total

\begin{tabular}{rrrrrrr} 
Pashtun & Tajik & Hazara & Turkmen & Uzbek & Other & Total \\
8,377 & 2,509 & 182 & 41 & 2,629 & 982 & 14,720 \\
10,625 & 2,953 & 5 & 1,076 & 2,409 & 1,047 & 18,115 \\
13,026 & 608 & 10 & 664 & 3,085 & 129 & 17,522 \\
9,483 & 5,883 & 71 & 1,513 & 4,573 & 1,235 & 22,758 \\
11,277 & 11,271 & 3,684 & 656 & 4,225 & 340 & 31,453 \\
3,756 & 5,898 & 156 & 224 & 4,255 & 1,104 & 15,393 \\
837 & 114 & - & 2,520 & 219 & 63 & 3,753 \\
\hline 57,381 & 29,236 & 4,108 & 6,694 & 21,395 & 4,900 & 123,714
\end{tabular}

Note 1. During this period a total of 2,417,105 A fghans were repatriated from other countries. Some 82 percent of them had been refugees in Pakistan, and 18 percent in Iran. The percentage of repatriation from other countries was negligible. The refugees returning to Kunduz constituted 5 percent of all returnees to Afghanistan during the period.

Note 2. As for the Assisted IDP Movement Programme run by UNHCR from different districts in Afghanistan to district of origin from January to March 2004, Khan Abad was among the top five districts in the country.

Note 3. In March 2004, there were 1,970 IDPs registered by UNHCR in Kunduz. That number constituted about one percent of all IDPs in Afghanistan. 
Education:

Health:

Disability:
Many schools have been built during the past two years, and many more are needed. Primary school enrolment is below the national average of $67 \%$ for boys and $40 \%$ for girls; in Kunduz, the percentage for boys is $57 \%$ and girls $36 \%$. There is a great need for more teacher training, especially for female teachers, and curriculum development. The Child Fund Afghanistan (CFA) and SCA are the most active NGOs in primary education. See Chapter 8. Primary and Secondary Education.

Many new health clinics have been built, equipped and staffed in the past two years, and many more are needed. Afghanistan's health indicators are among the worst in the world, with large gender gaps, e.g. almost half of all deaths among women of reproductive age are a result of pregnancy and childbirth. Only $3 \%$ of mothers in Kunduz give birth in a health facility. SCA is the implementing partner to the Ministry of Health for the Basic Package of Health Services (BPHS) in Kunduz. See Chapter 9. Health.

Disability rates due to polio, cerebral palsy, and conflict and accidents (including landmines) are very high. SCA is the only NGO providing services for the disabled in Kunduz on a permanent basis. See Chapter 10. Disability.

Provincial administration: Provinces are graded largely by population, but there are additional political factors influencing the assignation. Grade 1 is the largest, and grade 3 is the smallest. Kunduz is classified as grade 1 . The grade affects the size of the governor's office, as well as the position grades of the staff. $A$ Guide to Government in Afghanistan and Subnational Administration in Afghanistan: Assessment and Recommendations for Action, two recent publications published by the Afghanistan Research and Evaluation Unit (AREU) and The World Bank (2004), give a useful overview of provincial administration. 


\section{WARLORDS AND OTHER POWER HOLDERS}

"... The American attack assumed a military strategy that avoided ground combat and the resulting threat to U.S. forces. The strategy of aerial bombardment, while capable of punishing the Taliban, lacked the ground troops necessary to secure territory. To carry out this task, the United States needed local troops, and for this the United States physically brought back the warlords, rearmed them, financed them, supported them militarily, and reinstalled them in power. The CIA simply handed suitcases of cash to warlords around the country. This investment allowed local commanders to resume their former positions and rearm themselves, ostensibly to take on the Taliban. It also gave them the seed money to become self-sufficient by engaging in smuggling, drug trafficking, and general criminal activity. Predictably, their rule has been nasty and brutal, as grimly documented in numerous accounts gathered by Human Rights Watch researchers and others from throughout Afghanistan over the past two years.

... One thing that unites the Taliban and local warlords who are ostensibly allied with Karzai's government or U.S. forces is their opposition to any legitimate political process in Afghanistan that could return peace and civility to the country."

Sam Zia-Zarifi, Human Rights Watch World Report, 2004

"The United States is betting that the same men who caused Afghanistan so much misery in the past will somehow lead it to democracy and stability in the future. The evidence, however, suggests the opposite is happening. Opportunities have been lost, goodwill squandered, and lessons of history ignored...

... the ferocious killing of the mid-1990s. They [the warlords] still maintain private armies and private jails and are reaping vast amounts of money from Afghanistan's illegal opium trade valued at close to $\$ 2.3$ billion last year - as well as from extortion and other rackets.

... The warlords have now ruled the country for two years, and Afghanistan seems to be degenerating into a sort of narco-state, which could spin out of control... The warlords have stolen peoples' homes, arbitrarily arrested their enemies, and tortured them in private jails... The main victims of all this have been ordinary Afghans.

... If Washington really wants to help, it must abandon its policy of working with the warlords and factional leaders of the Northern Alliance. Sayyaf, Fahim, and their men have nothing to offer Afghanistan that would help the country move forward. Concessions made to the warlords will be met only with demands for more concessions.

Kathy Gannon, Afghanistan Unbound, Foreign Affairs, May/June 2004 


\section{Who Controls Subnational Administration?}

District and provincial officials interviewed felt that Kabul's influence was very limited at the subnational level:

"It's only in name that we have a system of government - it doesn't exist in reality. I'm the acting governor but I have no authority. I can only sign but I have no feeling of responsibility I don't have the power to say 'no."' (Acting provincial governor)

"Mujahidin commanders still hold power. All the mujahidin groups are getting stronger again because they don't think the government will do anything against them." (Provincial governor)

"The international community made a big mistake by giving a clear mandate and strong support for regional warlords to rebuild their bases of power. Mujahidin commanders were appointed to some key positions. Within 18 months, the government couldn't change governors, commanders, chiefs of police." (Provincial mayor)

From A Guide to Government in Afghanistan, AREU \& The World Bank, 2004

\section{The Importance of Disarmament}

"In one district the head of the education department was replaced. But because he had armed supporters he was reappointed in three days." (Teacher)

"If you want good administration, the first thing you need to do is disarmament. There's a big difference between saying and doing. We've heard a lot about disarmament on the radio, but we are seeing nothing." (Citizens group)

"The two biggest issues are disarmament and salaries. Until there is disarmament we won't get good security, and until government employees eam enough to survive on and get paid regularly the government system cannot function properly. If these two things are done the law will be ruling - today the Kalashnikov is the law." (Deputy head of police)

"If I don't have a commander around, immediately I become strong and get respect. If there are armed people around, I can't say anything." (District governor)

"If higher authorities accept disarmament then lower authorities will. If higher authorities don't accept, lower ones won't either. If those who have power at the centre agree to disarmament, everyone lower down the chain of command will accept. Those with power to construct and destruct at the centre are the problem, not those at the provincial and district levels." (District governor.)

"Unless the commander issue is dealt with no one will be successful in rebuilding Afghanistan." (Deputy governor)

From A Guide to Government in Afghanistan, AREU \& The World Bank, 2004 
Formally (de jure), Afghanistan is one of the most centralised states in the world. In reality (de facto), however, the country has become highly fragmented during the last 25 years, with regional leaders, so-called warlords, and local commanders operating in relatively distinct geographic areas and, at times, cooperating in loose alliances to gain control of, or to resist, the centre. President Karzai and his government have weak national institutions, and they lack military, administrative and financial control in major parts of the country.

The power of the warlords and commanders rests not only on military strength, but also, to a large extent, on financial strength coming from a variety of sources, not least the narcotics trade, customs revenues, land and property seizures, abuses related to water and irrigation, and unofficial taxation, including taxes on productive activities and transport. Their power may also be based on personal, ethnic, factional, and historical loyalties.

When MSF (Médicins Sans Frontières/Doctors Without Borders), the medical humanitarian NGO, decided to leave Afghanistan in July 2004 after 24 years of service in the country, its principal complaint was that the Afghan government had failed to act on evidence that local commanders were behind the deliberate attack with grenades and gunfire leading to the murders on 2 June 2004 of five members of its staff in the north-western province of Badghis. In a press release, MSF wrote:

\begin{abstract}
"Although government officials have presented MSF with credible evidence that local commanders conducted the attack, they have neither detained nor publicly called for their arrest. The lack of government response to the killings represents a failure of responsibility and an inadequate commitment to the safety of aid workers on its soil.

... After having worked nearly without interruption alongside the most vulnerable Afghan people since 1980, it is with outrage and bitterness that we take the decision to abandon them. But we simply cannot sacrifice the security of our volunteers while warring parties seek to target and kill humanitarian workers. Ultimately it is the sick and destitute that suffer."
\end{abstract}

Marine Buissonnière, Secretary General of MSF, 28 July 2004

\title{
The most powerful man in Kunduz is Brigadier General Mohammad Daoud Andrabi
} Khan, the Commander of the $6^{\text {th }}$ Corps. Daoud, a former deputy to assassinated Ahmed Shah Masoud of the Northern Alliance, is the regional warlord in the northeast of Afghanistan. Daoud is an ethnic Tajik from Takhar, and he belongs to the Jamiat-e-Islami Party. Reportedly, he is not respected by ordinary people in Kunduz. Daoud has full control of the present Provincial Governor. Daoud is affiliated to and supported by the powerful Defence Minister Fahim, one of the most powerful men in Afghanistan. His relations with Commander Mir Alam are tense.

Demobilisation and disarmament under General Daoud is proceeding slowly, behind schedule. Presumably, he is reluctant to surrender weapons and fighters for fear of losing power. Earlier this year, he said: "If anyone thinks we are ready for elections, he's lying. But if we must have elections, those people in the south should not be allowed to vote." (The Guardian, 12 March 2004)

Commander Mir Alam is in charge of the $56^{\text {th }}$ division. He is an ethnic Tajik from Kunduz, and, reportedly, the least unpopular man among the top military leaders in Kunduz. At times, there are strong tension between Mir Alam and Daoud. Mir Alam comes from a landless, poor 
family. He started as a milk-seller, and now he is a wealthy man with plenty of valuable property.

The Provincial Chief of Police is Motaleb Beg, an ethnic Uzbek from Taloqan in Takhar, affiliated to General Dostum. In February 2004, Motaleb Beg was captured by ISAF and Afghan police in Kabul with 300 kilos of heroin. Both Motaleb Beg and the heroin were handed over to the Kabul police with instructions how to handle the case. The following day the heroin had disappeared.

In Kunduz, the provincial system is infiltrated by commanders, at all levels. Every district and every village have commanders as local power holders. Conflicts are common, but killings are rare. Village elders have very limited influence.

Abdul Rauf from Imam Sahib is the most powerful Uzbek commander in Kunduz. He has a shameful human rights record. He is the brother of Amir Latif, currently Provincial Governor in Faryab, earlier Provincial Governor of Kunduz. Abdul Rauf left Hizb-e-Islami to join Jamiat-e-Islami. At present, he is said to cooperate with Junbish and maintain contacts with Hizb-e-Islami. He is well-known for smuggling across the border to Tajikistan. (Reliable source, November 2004)

Local commanders have been most reluctant to hand over customs revenues to Kabul, often treating them as personal income used partly to fund private armed groups. At Sher Khan Bandar and Ai Khanum, it is estimated that local commanders earn $\$ 20,000-\$ 50,000$ per week from customs revenues. Commanders also demand taxes on harvests and livestock (including 10 percent zakat). Other sources of income are forced farm labour and bribes for allowing rural families not to send their sons into military service. Officially, direct pay to commanders from the U.S. was stopped in December 2003. In any case, the commanders' loyalty was not really for sale, but just for rent. (Unofficial but usually reliable source)

There have been reports that General Abdul Rashid Dostum, Afghanistan's foremost ethnic Uzbek warlord and leader of the Junbish Party, tried to expand his influence to areas where Uzbeks are significant minorities or even majorities in Kunduz in December 2001, when his troops were chasing the Taliban. Some Uzbek and Turkmen commanders in Kunduz appeared to welcome Dostum, among them Abdul Rauf in Imam Sahib, but Jamiat-e-Islami succeeded in stopping Dostum's plans.

Since March 2004, the Provincial Governor of Kunduz is Engineer Mohammad Omar Khan, an ethnic Pashtun from Takhar. Earlier he was Governor of Baghlan, where many district commanders refused to follow his orders. In Kunduz, he is controlled by General Daoud. Mohammad Omar used to be a member of Abdul Rasul Sayyaf's Ittehad-e-Islami Party, a deeply conservative follower of the Wahabi sect of Islam, receiving much of its funding from Saudi-Arabia. Reportedly, the Governor earlier kept a private prison in Baghlan. Mohammad Omar became one of Jamiat-e-Islami's commanders in 1997.

Women in power. There are no women in powerful positions at the provincial or district levels. According to IOM, there are some strong women's shuras in Kunduz. For a list of women working for human rights for women, see Chapter 5. Women and Human Rights. 
The following quotation comes from The Human Rights Watch publication "The Rule of the Gun: Human Rights Abuses and Political Repression in the Run-up to Afghanistan's Presidential Election" (September 2004):

"A politically active woman from Kunduz said the elections would be marked by abuses, and blamed the poor political situation on failures to disarm militia leaders in the north: I do not think the elections will be very fair. It will be unfair, because the DDR [disarmament, demobilisation, and reintegration] has failed in Afghanistan. Some guns were collected from people but that was symbolic, not real. These elections will also be symbolic, not real. It will just teach them about what elections are, but it will not be real."

Human Rights Watch, September 2004

Religious leaders. There is no major religious leader with a large following in Kunduz. 


\title{
4. THE SECURITY SITUATION FOR NGOS
}

\begin{abstract}
"There is widespread agreement among Afghans and international observers that there can be no reconstruction without security, and there can be no security without reconstruction. In Afghanistan, as in other post-conflict situations, construction crews cannot build roads, clinics, or schools if they face threatening forces; armed groups will not give up the way of the gun unless they can make a living and protect their families and livelihood without it."
\end{abstract}

Sam Zia-Zarifi, Human Rights Watch World Report, 2004

Germany runs a Provincial Reconstruction Team (PRT) under civilian-military leadership in Kunduz. Since 30 December 2003, the military component of the Kunduz PRT has been answerable to ISAF. As of September 2004 , the Kunduz PRT is staffed by 270 peacekeeping troops and some 30 civilians, including medical staff. The proclaimed aim of the PRT project is to bolster the authority of the central government in the province and promote stabilisation and reconstruction.

In April 2004, 208 police officers from Kunduz, Takhar, Badakhshan and Baghlan graduated from the Kunduz Police Academy, and an additional 193 started training under the Transition Integration Programme (TIP). The training courses lasted two weeks for literate officers and four weeks for illiterate officers. The training at the Kunduz Police Academy is run by Germany, the lead nation assisting with reform of the Afghan police. The TIP is a US funded initiative.

In April 2004, Colonel Ferdinand Baur, commander of the German PRT based in Kunduz, described the situation in the northeast as "quiet, but not stable". Two months later, eleven Chinese road construction workers were shot dead and four others seriously injured. They worked in a World Bank funded project to reconstruct the Pul-e-Khumri - Shir Khan Bandar road $(163 \mathrm{~km})$. A week later, four Afghans, including two children, travelling in a PRT vehicle in Kunduz City were killed in a bomb blast.

In September 2004, a convoy carrying Vice President Nematullah Shahrani was the target of a roadside bomb attack on the road between Kunduz City and Taloqan. Shahrani was unhurt, but one driver was injured.

In spite of the attacks mentioned above, Kunduz is generally considered a fairly calm province. Three weeks before the presidential election on 9 October 2004, ANSO (The Afghanistan Non-Governmental Organisation Security Office) wrote in its weekly report (17 -23 September 2004):

\footnotetext{
Kunduz Province

The security situation in all parts of this province has remained calm during the reporting period. The road between Taloqan and Kunduz cities is known to be a constant security issue for all international agencies that plan to travel on it. ANSO again advises all NGOs to be cautious and to contact us for updates before moving to this road. Based on the incident [attempted attack on Vice President Nematullah Shahrani travelling with General Daoud, World bank representatives and an American security unit] between Kunduz and Taloqan road, ANSO strongly advises all NGOs not to travel or move close to security forces (PRT, ISAF, Police) or high-ranking authority vehicles..
}

ANSO Weekly Report, 17-23 September 2004 


\section{WOMEN AND HUMAN RIGHTS}

"Women and girls bear some of the worst effects of Afghanistan's insecurity. Conditions are generally better than under the Taliban, but women and girls continue to face severe governmental and social discrimination. Those who organise protests or criticise local rulers face threats and violence. Soldiers and police routinely harass women and girls, even in Kabul city. Many women and girls are afraid to remove the burqa. Because soldiers are targeting women and girls, many are staying indoors, especially in rural areas, making it impossible for them to attend school, go to work, or actively participate in the country's reconstruction. The majority of school-age girls in Afghanistan are still not enrolled in school."

From Human Rights Watch Report, January 2002

Amnesty International published a report called "No one listens to us and no one treats us as human beings': Justice denied to women" in October 2003. In the report, Amnesty International expressed grave concern by the extent of violence faced by women and girls in Afghanistan. The risk of rape and sexual violence by members of armed factions and former combatants was still high. Forced marriage, particularly of girl children, and violence against women in the family were widespread in many areas of the country. These crimes of violence continued with the active support or passive complicity of state agents, armed groups, families and communities. This continuing violence against women in Afghanistan was seen as a cause of immense suffering and a denial of women's fundamental human rights. The following excerpts (edited) come from the report:

- Violence against women. Women and girls are vulnerable to rape, sexual violence and abduction. They are threatened with violence in every aspect of their lives, both in public and private, in the community and the family. Violence against women in the family, including physical abuse, is widely reported. The extent of the problem emerges more clearly in hospitals than in any other state institution, when severely injured women seek treatment.

- Adultery. In certain regions of Afghanistan, women accused of adultery are routinely detained, as are those who attempt to assert their right under Afghan law and international standards to marry a spouse of their own choice. "Running away from home", adultery and other unlawful sexual activity, including consensual sex outside marriage, are referred to as zina crimes. They are subject to criminal prosecution. (The zina offence is part of the Afghan Penal Code.) Some women in such circumstances are also at risk of being killed if released. In some cases, she may be killed, but her death is made to appear as suicide.

- Impunity and the failure to provide justice and protection from abuse perpetuate violence against women as the perpetrators do not consider themselves criminal.

- So-called honour crimes. The Penal Code also permits mitigation of sentences for murders claimed to have been committed in defence of honour. For example, a husband who murders his wife when she is found committing adultery is exempted from punishment for murder on that basis.

- Protection and shelters for women at risk have not been created, and legal aid provision remains entirely adequate.

- Un-Islamic. Progress and emancipation for women have been characterised by some political forces as un-Islamic and contrary to Shari'a (Islamic law).

- Forced and underage marriage also occurs when women and girls are given away into marriage as a means of dispute resolution by informal justice means, for example in cases of indebtedness.

- The legal age for marriage in Afghanistan for men is 18 and for women 16 years of age. (Many people do not know their exact age.) Age of marriage varies between urban and 
rural areas and according to ethnic background and economic circumstances. Often, girls and women are treated as an economic asset, with families receiving a price from the family of the groom. There are many reports of underage marriage, with girls as young as ten and even younger. Rural girls normally drop out of school after marriage. Many adolescent girls die in childbirth, as their bodies have not reached full physical maturity.

- Loss of virginity outside marriage is devastating for unmarried girls and young women.

- Rape. No support or professional services are available to women victims of rape. Women coming forward to report rape risk being accused of adultery and detained for zina under the Penal Code. A common form of suicide by rape victims is self-immolation (death by fire).

- Women prisoners. There are several unconfirmed reports of sexual abuse of women prisoners in official detention centres and police stations.

- Women's rights. Women are largely unaware of their rights under international law and also, to an extent, their rights under Afghan and Shari'a law. In many communities, women cannot leave the home without an accompanying male relative, so-called mahram. To be seen to travel alone might result in loss of reputation. In rural areas, there is a lack of communications and transportation infrastructure. Telephone facilities are rare. Many women live in extreme isolation, further aggravated by illiteracy and lack of money.

- Lack of certainty and consistency over legal sources. An Afghan women's rights activist with experience from legal proceedings said: "Judges will choose between written law, custom and Shari'a according to which suits the interests of the man."

In general, the human rights situation, as described above by Amnesty International, is applicable to Kunduz, according to SCA staff. Women are denied fundamental human rights. Underage marriages, forced marriages and domestic violence are common. Freedom of movement for women is highly restricted. Most women live in extreme seclusion. Few dare or are allowed to venture out of the home. Mahram and chadri (burqa) are 'musts', also for most young well-educated women who would like to work outside the home.

The primary school enrolment rate for girls in Kunduz is 36 percent (and 57 percent for school-aged boys). That is lower than the national average rate of 40 percent for girls (and 67 percent for boys). The enrolment rates are especially low for Turkmen girls in Qala-e-Zal district. They are engaged in carpet-weaving at home. The enrolment rates for Uzbek girls are also very low, all over the province. See Chapter 8 . Education. 
Below are the stories of two girls from Kunduz, Jamila, 16 years old, and Rahima, 12 years old. Both are at risk of being murdered in so-called defence of honour.

Jamila, 16 years old, forced into marriage, abused, raped and imprisoned
"I remember Jamila, a 16-year-old Afghan girl whom I met in the women's prison in Kabul in
July this year. The prison was full of women accused of adultery, of running away from brutal
husbands or of wanting to marry the men of their choice. Jamila was abducted from her home in
Kunduz a year ago when she was just 15 , forced into marriage, abused and raped. Caught by the
police, she was sent to prison for deserting her husband. Jamila told me that she would like to go
home to her parents. But she is afraid that her father will kill her because, according to him, she
has soiled the family honour - or if not her father, the man who had abducted her certainly
would.
In 2003 , President Karzai granted amnesty to twenty such women, but on their release four of
them were instantly killed by their own families - victims of so-called honour crimes - and
several others have 'disappeared'."
Excerpt from speech by Ms Irene Khan, Secretary-General,
Amnesty International, 25 November 2003

Rahima, 12 years old, kidnapped and raped. What next?

... kidnapped on her way home from school... After 18 days of detention, during which she was raped, Rahima was recently released by law enforcement agencies...

Rahima was the second girl from the same school to be kidnapped this year, while three girls were reportedly found dead in Kunduz.

... In an effort to crack down on child kidnapping, President Hamid Karzai issued a decree in June imposing the death sentence on those found guilty of killing a kidnap victim. He also increased the jail term for those guilty of injuring an abducted child.

... Today, Rahima lives in the home of a private Kunduz resident, Haji Edembirdi, who has been chosen by a Council of Elders to protect her. The council fears that if she returns home, some of her relatives might kill her to remove what they see as a stain on the family's honour. Honour killings are a pre-Islamic practice in which a woman is murdered or punished corporally usually by male members of families - for her actual or perceived immoral behaviour.

... "Some of those people who kidnap girls have contacts with government officials. They are friends or from the same tribe. Government officials cannot prevent such actions. They cannot stop them," Edembirdi said. "Residents are now afraid to send their girls to school."

From Radio Free Europe/Radio Liberty, 3 December 2004

The official "mission" of the Ministry of Women's Affairs is "to ensure that Afghan women's legal, economic, social, political, and civic rights including their right to be free from all forms of violence and discrimination are respected, promoted and fulfilled." For 1383 (2004/05), the Ministry and the 29 Provincial Departments of Women's Affairs (DWA) have a total budget of $\$ 1.25$ million, a drop in the ocean.

The Provincial Department of Women's Affairs (DWA) was established in Kunduz in 2003 to focus mainly on the rights of women and job opportunities for women. Literacy classes for women are held in at least two districts. The DWA Centre is located in Kunduz City. Director is Ms Affa, an ethnic Tajik and teacher. Deputy Director is Ms Khurshid, an ethnic Pashtun and teacher.

Strong social and cultural norms continue to limit women's public role in Kunduz. There are, however, examples of educated women, in addition to the two mentioned above, who are in positions to promote human rights for women: 
Ms Moslema Walwaliji, 45 years old, Director of Rozan-e-Solh, a women's NGO with a daily newspaper called Saeqa (Thunder). She is an ethnic Tajik and a teacher by training. Elected delegate at the Constitutional Loya Jirga.

Ms Nafisa Sadiqi, 46 years old, teacher at the Lycee Khatijatel Kobra Women's School. She is an ethnic Tajik and a teacher by training. Elected delegate at the Constitutional Loya Jirga.

Dr Zarmina Hassan, Director of the Women's Civil Society Union, is promoting women's rights, including the right to participate in the presidential election. She is a medical doctor by training.

Ms Alia Ghizal Kohi, an ethnic Tajik, delegate at the Emergency Loya Jirga. Worked in the Cultural and Media Section for the Mujahidin in Pakistan. Well-known in Mujahidin circles.

Ms Mahbooba, Headmaster of the Bibi Fatima-e-Zahra High School in Kunduz.

Ms Shafiqa, from Khan Abad, former teacher, staff member of the SCA Education Sector.

Ms Najia Khudayar, Director of Radio Zohra, a women's radio station in Kunduz City. 


\section{THE OPIUM ECONOMY}

After the fall of the Taliban in 2001, opium production has become Afghanistan's leading economic activity, accounting for half of the nation's gross domestic product and five times the annual budget of the central government. (Pakistan Tribune, 22 June 2004) It is a source of funds for the Taliban and their allies, as well as the Al Qaeda and powerful warlords and commanders. Moreover, top-level government officials are deeply involved in the opium economy.

The World Bank (2004) points out that "the impact of the drug industry on Afghanistan's economy, polity and society is profound, including some short-run economic benefits for the rural population and macro-economy but major adverse effects on security, political normalisation and state-building."

The 2004 opium harvest is expected to be the biggest ever in Afghanistan, and the proportion of opium refined to heroin inside Afghanistan is continuing to rise. Now up to 90 percent of the illegal drug exports from Afghanistan is heroin, according to the United Nations Office on Drugs and Crime (UNODC). The drug industry has a strong interest in maintaining an environment of insecurity and lawlessness.

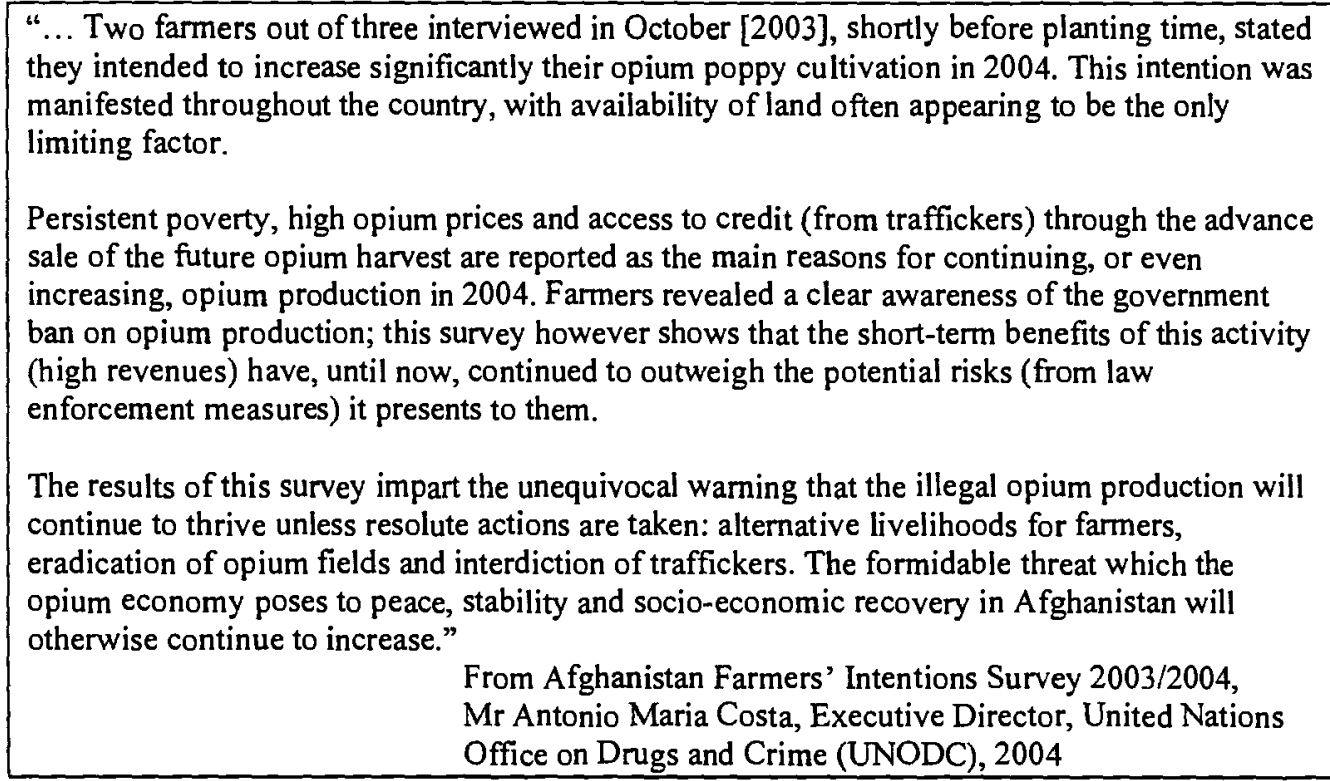

Some other data from the Afghanistan Farmers' Intentions Survey 2003/2004 are as follows:

- The opium harvest in 2003 was 3,600 metric tons, the second largest ever (after 1999).

- The harvest accounted for more than 75 percent of the world's illicit opium production [and 95 percent of Europe's consumption].

- 69 percent of all farmers interviewed in poppy growing regions reported intentions to increase poppy cultivation in 2004,16 percent to keep it stable and only 4 percent to reduce it ( 11 percent did not answer).

- 75 percent of all village headmen interviewed expected opium cultivation to increase in their villages in 2004 .

- Intended increases were reported from all parts of the country, but were particularly pronounced in the northern provinces, and least pronounced in the east. Kunduz showed 
an average increase of 10-100 percent, with Kunduz District and Ali Abad at a stable level and more remote areas increasing substantially.

The main reasons to grow opium poppy were:

- to alleviate poverty ( 31 percent of the farmers' replies; 30 percent of headmen replies)

- high opium prices ( 30 percent farmers; 28 percent headmen)

- to get credit (salaam arrangements, i.e. advance sale of the future harvest, important for the very poor and indebted in the absence of a rural credit system) (18 percent farmers; 18 percent headmen)

- to purchase 'luxury' items, e.g. motor-cycles ( 7 percent farmers; 6 percent headmen)

- expected compensations from eradication ( 6 percent farmers; 6 percent headmen)

The main reasons not to grow were:

- it is against Islam ( 24 percent farmers; 17 percent headmen)

- it is illegal (23 percent farmers; 17 percent headmen)

- fear of eradication (17 percent farmers; 16 percent headmen)

- fear of imprisonment/fines (16 percent farmers; 16 percent headmen)

- unfavourable climatic/soil conditions (11 percent farmers; 7 percent headmen)

The UNODC Survey showed that in 2003, the average income from poppy was $\$ 12,700$ per hectare, much higher than the income from wheat, the main alternative crop, which was $\$ 222$ per hectare. The relationship given by The World Bank (2004) is 27:1.

"We wamed people we would punish them if they grew poppy, but in some areas local
commanders encouraged farmers to grow, saying central government is week and won't do
anything. They have their own interests in mind as they tax the poppy. There's now no war on so
the commanders are looking for alternative livelihoods." (Provincial governor)
"Poppy cultivation and processing is strongly supported by commanders and police. They are
very involved and take their share. No one could produce poppy if they did not allow it... opium
and heroin is transported in with official plates." (District administrator)
The poppy business is linked to important people in Kabul and there is no support from Kabul to
fight with commanders - they have more money than we do." (General of provincial garrison)
From A Guide to Government in Afghanistan, AREU \&
The World Bank, 2004

In summary, in spite of religious and cultural aversion, opium poppy cultivation is attractive to farmers for many reasons, including

- good income and guaranteed market

- credit and other inputs are available from the traffickers

- poppies have higher drought-resistant qualities than most crops

- easy to transport and non-perishable

- limited law enforcement

Since most rural poor households depend more on wage income than farm income, they benefit from high demand for labour for poppy cultivation and harvesting. Skilled poppy workers may earn up to $\$ 12$ per day during the harvest period, as compared to $\$ 2-3$ for unskilled workers in other fields. (The World Bank, 2004)

Women and girls. According to the World Bank (2004), women play a very important role in poppy cultivation in northern and eastern Afghanistan. Opium production is labour intensive 
and women are involved in planting and weeding, thinning, lancing the capsules, collecting the opium, clearing the fields, breaking the capsules and removing the seeds, and processing by-products like oil and soap. Due to local labour shortages, women are, in fact, often for the first time being paid wages. On the tragic side, young daughters are often given away to settle debts related to opium.

According to Mirwais Yasini, the Director of the Afghan Counternarcotics Department in Kabul, there are more than 30,000 opium addicts in Kabul. Few will admit that they are addicted since opium is considered unclean and forbidden by Islam. Yasini also stated that poppy growers, brokers and traffickers enjoy the protection of police chiefs, militia commanders, provincial governors and even Cabinet ministers. (Pakistan Tribune, 22 June 2004)

Initially, the British which are leading international efforts to combat Afghan drugs, offered farmers money to destroy their poppy crops. As word spread, many grew poppies deliberately, expecting British cash. When the cash did not come they sold the opium. In 2004, there has been widespread confusion about A fghan government policy among farmers, according to General Daoud. It has been decreed that 25 percent of this year's crop should be eradicated. According to General Daoud, many farmers have interpreted that to mean that the other 75 percent are legal.

Until very recently, neither the US-led coalition forces nor the NATO-led International Security Assistance Force have made counter-narcotics part of their operational mandate.

At a congressional hearing in Washington D.C. on 23 September 2004, an official from the Bureau of International Narcotics and Law Enforcement Affairs announced that the CIA's Counter Narcotics Centre had estimated last year's poppy crop at 61,000 hectares, with a likely increase to some 100,000 hectares this year. This would mean a dramatic increase. There were record levels of poppy production in areas not previously used for this purpose. Pentagon official Peter Rodman said: "We know that profits from the production of illegal narcotics flow into the coffers of warlord militias, corrupt government officials and extremist forces." (BBC/Radio Free Europe, 24 Sept 2004)

\footnotetext{
Mr Antonio Maria Costa, the Head of the UN Office on Drugs and Crime visits Kunduz, 29 May 2004

After lunch, there is another illustration of the scale of the challenge, with a visit to a poppy field. It looks like any other, except there was no poppy-growing here last year. Nor was there much elsewhere in the rest of Kunduz. But all that's changing. Even in traditionally lowproducing areas, farmers are sowing the crop, anxious not to be left out.

The 78-year-old farmer is found in the huts nearby.

- "Yes, it's the first time I've grown it," he admits reluctantly.

- "But why this year?" demands his Italian visitor [Antonio Maria Costa].

- "Well everyone else is doing it, so why shouldn't I?"

Laughter from the crowd of officials and soldiers looking on.

- "But don't you know this is against Islam?" says Mr Costa, holding up a poppy bulb.

The farmer looks up plaintively.

- "There is freedom now, it's a democracy isn't it?"

The crowd roars.
} 
- "No, I understand, you make more money," Mr Costa counters. "If I rob a bank, I make more money, but it's against the law. I'll come back next year and I want to see you in good shape and without poppy, okay."

There's a pause, then the farmer says:

- "Okay, next year, 1 will only grow it with your permission."

There is another explosion of laughter from the officials and soldiers, many of them chewing on opium seeds from poppy bulbs they have broken open.

From a BBC interview, 29 May 2004

The soldiers of the Kunduz PRT are operating in one of the most opium rich areas of Afghanistan. However, the German parliament only agreed to the deployment of the force outside the relative safety of the ISAF mission in Kabul on condition that the soldiers of the PRT keep out of the fight with the drug barons. (Deutsche Welle, 9 February 2004)

Opium is openly bought and sold on various markets, including the Kunduz City bazaar which is one of the central places for drug trafficking and dealing in raw opium in northern Afghanistan. Ali, a local farmer, harvested 7 kilos of raw opium last year. At a price of about $\$ 300$ a kilo, he earned almost $\$ 2,100$ - enough to help his wife and eleven children survive the long bitter winter. In Europe, 7 kilos of opium refined into 700 grams of pure heroin would cost 070,000 . (Deutsche Welle, 3 January 2004)

In the Central Prison of Kunduz, there were some 100 male prisoners at the end of 2003. According to Abdul Halim Samanwal, the Prison Director, the jail register showed 42 murderers, 27 thieves, 14 rapists and adulterers, ten homosexuals and one person arrested for drug-dealing. (Deutsche Welle, 3 January 2004) 


\section{AGRICULTURE}

Since 2002, there has been an extraordinary growth in agricultural production in Afghanistan. Total cereal production (mainly wheat) increased by 82 percent in 2002, and by an additional 50 percent in 2003, reaching 5.4 million tons, theoretically covering the food grain consumption needs for Afghanistan. The 2003 cereal production was estimated to be one of the largest ever recorded. Also other crops, including potatoes and melons, were extremely successful. A return to normal rainfall in parts of the country after several years of drought, and improved availability of seeds and fertilisers have facilitated the growth. Production of fruits, vegetables and livestock products has also increased since 2002, but is not yet back at pre-conflict levels.

Agriculture, half of the Afghan economy, is critical for future growth, poverty reduction, and export development. According to The World Bank (2004), there is more or less consensus on the main problems and constraints which need to be acted upon to accelerate agricultural growth. Key priority areas include the following:

- Rehabilitation and management of water resources

In addition to civil engineering and hydrology challenges, there are problems with distribution of the available water. Who gets how much, when and where? The traditional community-based mechanisms for water management and maintenance have been negatively affected by local commanders who often do not respect the water rights and/or the authority of the mirabs (water masters).

- Agricultural research and extension

- Facilitation of modern post-harvest handling and marketing

- Improved access to rural finance, including micro-credits

- Land tenure insecurity

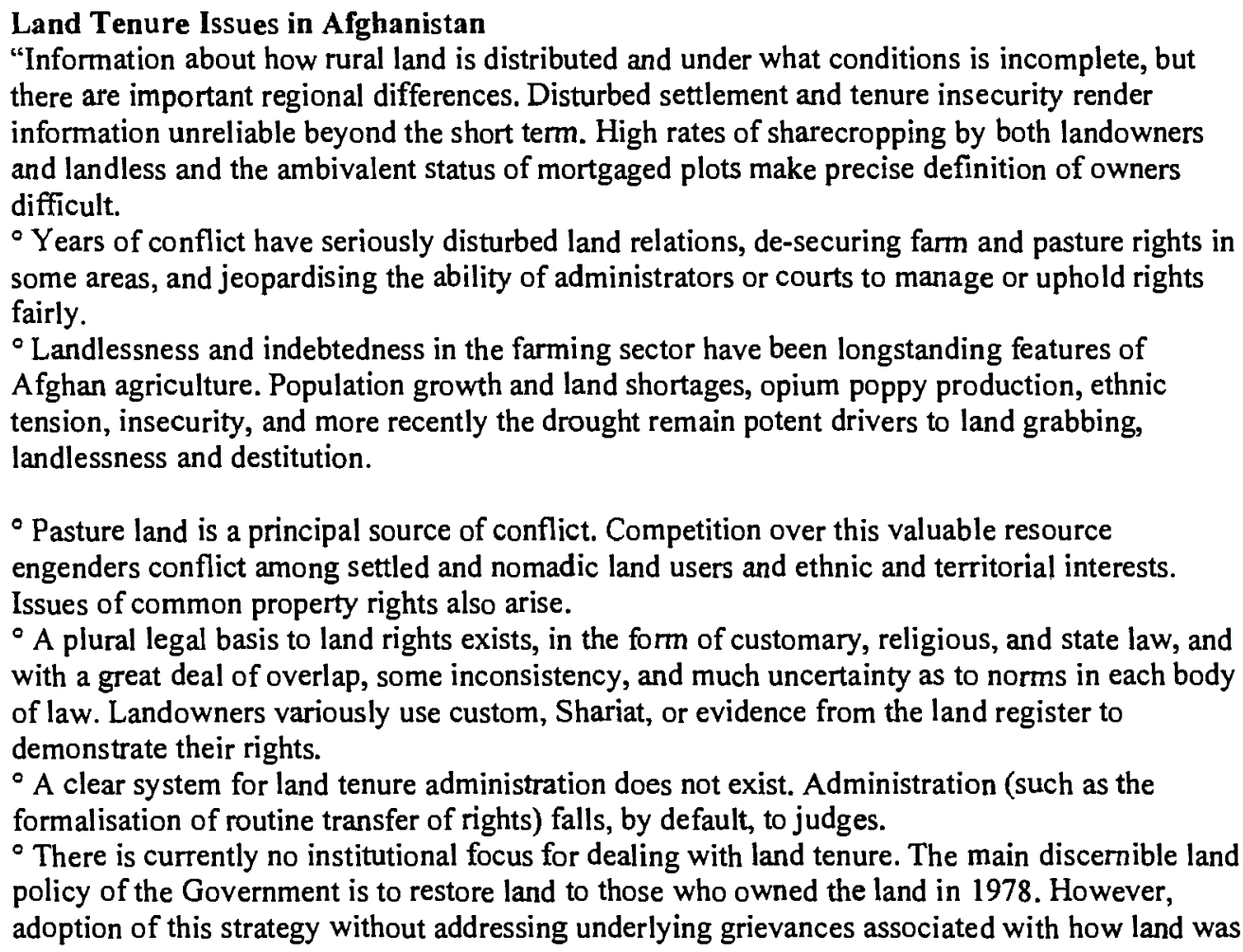


acquired will not provide a lasting resolution. A second main policy is to pursue registration and entitlement, mainly to encourage investment. This deserves more thought in light of the failure of registration approaches to deliver tenure security."

Source: Wily (2003) From "Afghanistan: State Building, Sustaining Growth, and Reducing Poverty. A Country Economic Report," The World Bank, 2004

Landlessness and indebtedness. According to Christoplos (2004), several recent studies show that indebtedness resulting in landlessness is an increasing problem in Afghanistan. There are also many reports about destitute families being forced to leave their daughters into pre-mature marriages in settlement of debts. Large numbers of refugees and IDPs are unable to return home as they lack access to land and housing due to hostile occupation, fraudulent deeds and lack of effective property recording systems or adequate dispute resolution mechanisms.

\begin{abstract}
"Amnesty Intermational interviewed a group of Uzbek villagers, who had fled to Pakistan to escape the persecution of Turkmen Taleban in their native Imam Sahib district [in Kunduz province), and who then returned in August 2002 unaware that the same group of Turkmen, now allied to the Jamiat-e-Islami faction, were still in control of the village and of their land. The Turkmen continue to threaten the Uzbeks, who are now forced to live in ruined buildings on the outskirts of the village, and are still denied access to their land.

... Many returnees Amnesty International spoke to have arrived back at their places of origin to find their land and/or houses occupied by other families, often with the backing of powerful local commanders.

... Unaccompanied women, in particular, often find themselves unable to access their land upon their return... Women are often denied access to traditional leaders, or even formal justice mechanisms, and can be severely disadvantaged in the absence of a male family member who is willing to plead the case on behalf of the female relative."
\end{abstract}

"Out of sight, out of mind: The fate of the Afghan returnees", Amnesty International, 2003

Regarding the impressive growth in agricultural production during the past two years, Christoplos (2004) comments: "The scattered but disturbing signs that this growth has resulted in limited improvement in livelihoods among the majority of rural people gives cause for grave concern. We simply do not know much about what is happening with regard to the third condition [Ability to challenge societal vested interests that seek to re-appropriate the benefits that accrue to the intended beneficiaries] for transforming pro-poor projects into propoor rural development. Fears of widespread and gross abuse of power in local processes related to farming suggest a need to design and monitor agricultural interventions in relation to rights and protection agendas. The question is how." (The interested reader is referred to Christoplos excellent report quoted above.)

Women in agriculture. In most cases, female-headed households are extremely vulnerable. Security of tenure and of other social and economic assets is particularly fragile for women. In a survey, the International Rescue Committee (IRC) estimated that 13 percent of the women interviewed were widows. The national percentage of female-headed households is not known, but it may well be high since often young girls are married to elderly men, and large numbers of men have died during the war.

Women's involvement in agricultural production is considerable, though largely unrecorded and un-monetised. The World Bank (2004) stresses the vital need to understand the extent to which gender aspects impact on ownership, cultivation patterns, division of labour, postharvesting processing, livestock raising, and dairy production. 


\begin{abstract}
"Gender roles and relations are often attributed to 'culture,' but it must be remembered that 'culture' is not static and unchanging. People may wish to hold on to the idea of 'culture' as a form of identity, especially after years of turmoil and for many, the experience of living in another country. However, culture can change, sometimes in unexpected ways. For instance, as discussed earlier, it appears that while women's mobility was more restricted under the Taliban, some women became the main income earners in the family. It has also been shown that economic reasoning can sometimes play a larger role than cultural norms in determining the allocation of labour.

... Women's activities, perhaps especially in agriculture, are often invisible, partly as many are carried out inside the home or compound and partly as their activities are sometimes not discussed if they go against the socio-cultural norms of what women should be doing. More effort is needed to understand what women and men are doing in different places and how these roles both stem from and serve to reinforce gender relations, decision-making and well-being.

... Tackling gender inequity and improving livelihoods opportunities are not separate agendas but are inextricably connected, as they are both concerned with providing people with the opportunities for a decent life.

... A better understanding would assist programme targeting and could be used not only in programme design but also in monitoring and evaluation."

From "Gender Roles in Agriculture: Case studies of five villages in northern Afghanistan," by Jo Grace, AREU, 2004
\end{abstract}

In the interesting AREU report "Gender Roles in Agriculture: Case studies of five villages in northern Afghanistan" (2004), Jo Grace shows how factors such as age, marital status, wealth/poverty and ethnic group can influence change and how flexible gender roles can be. The report is recommended reading for the SCA staff concerned.

Rural transport and trading. Poor roads and lack of security are severe obstacles to rural development. Afghan Pashtun trading and trucking groups have long played an important role in agricultural marketing throughout the country. They believe they are the biggest losers from the fall of the Taliban, and claim that trade volume has fallen due to the insecurity created by the re-emergence of the warlords. Under the Taliban there was a single tax on goods passing through their territories, now anything can happen. A series of incidents and harassment has emphasised the deep sense of insecurity among the Pashtun trading and trucking groups. This has led to higher transaction costs and a vacuum of rural services in many rural area.

\footnotetext{
"The strong economic and social linkages of Pashtun traders across regional borders make them a unique group with a lot of cash. Western diplomats in Kabul say the potential role the traders can play in the reconstruction and modernisation of Afghanistan is a largely untapped resource the government in Kabul has yet to recognise. Although their expressions of political partisanship remain muted by feared association with the Taliban, they say they are traders first, and Pashtuns later.

From "Afghanistan: The Problem of Pashtun Alienation", ICG Report No. 62, August 2003
}

\title{
KUNDUZ - A HIGH POTENTIAL AREA
}

In the highly interesting AREU report "Out of Step? Agricultural Policy and Afghan Livelihoods" by Ian Christoplos (2004), Kunduz Province is described as a high potential area. Agricultural land mainly consists of irrigated lowlands, rain-fed plains and low hills. Rain-fed production is quite reliable due to relatively plentiful rainfall and fertile soils. Large areas of Kunduz, however, are desert or semidesert plains. Please refer to Appendix II. Maps. 
Crops. In addition to opium poppies (see Chapter 6. The Opium Economy), the major crops are wheat, rice and cotton. A significant cereal surplus is produced in the province. In fact, some wheat and rice were not even harvested in 2003 due to sinking prices and labour shortage. Farmers came to the conclusion that they could not compete with imports, from neighbouring countries with subsidisation policies, to the food deficit areas of the south and urban markets due to high labour and transport costs. Formerly, seasonal labourers used to come from Badakhshan to harvest wheat. Now they prefer to stay at home to work in the expanding opium poppy economy where they get much higher wages.

According to the National Risk and Vulnerability Assessment (NRVA) for 2004, the current drought is the longest and most severe in Afghanistan's known climatic history. Of Afghanistan's 34 provinces, 31 are suffering from the prolonged drought in 2004 . The three exceptions are Kunduz, Takhar and Badakhshan. Based on market prices and satellite images of crop growth, NRVA estimates that 37 percent of the Afghan population will not be able to cover their basic food needs (at least $2,100 \mathrm{kcal}$ per capita daily) and non-food needs up to the harvest in 2005 . The corresponding figure the year before was 20 percent. Only one province in the country is expected to cover its basic food needs, and that is Kunduz. Good wheat harvests in Uzbekistan and Kazakhstan are expected to contribute to low wheat prices in the major northern markets.

Cotton. In the 1930s, a major land reclamation programme changed Kunduz, earlier a sparsely populated malarial swamp, into an attractive and economically successful province. Afghanistan's first efforts to industrialise had begun. Cotton was cultivated on a grand scale, and the population grew quickly. The Spinzar Corporation became the primary motor of the cotton economy of Kunduz and neighbouring provinces, including a sub-office (well known to SCA) in Pul-e-Khumri. In many respects, according to Christoplos, Kunduz's cotton economy was a model for the state-led agricultural development policies of the last century. During the war, the cotton production collapsed, but it was revived under the Taliban, on a small scale. The Spinzar Corporation still exists as a state-owned enterprise for processing raw cotton and cultivating fruit, under the Ministry of Light Industries. In 2003, there were 570 people on the payroll. Now efforts to re-establish production are made. Much of the machinery is still in working order or could easily be repaired, but operating costs would be high due to the age of the machinery and the need to rely on generators for power. Christoplos warns that the competition from heavily subsidised cotton production in other countries would affect the future viability of an Afghan cotton industry, e.g. the US subsidising its cotton farmers with more than $\$ 3$ billion per year, or $\$ 2230$ per acre; and the EU subsidising Greece with some 100 percent of cotton farm value. Strong competition also comes from Uzbekistan, the world's second largest cotton exporter, Tajikistan, Pakistan and China. Christoplos ends: "Paradoxically, it is partly the regional threats to Kunduz's current wheat and rice production that have spurred hopes that cotton can again emerge as the engine of growth."

Alternative traditional and new crops for domestic consumption and/or export. Due to logistics problems and the low profitability of cereals, diversification into 'high value - low volume' crops are recommended for Kunduz. Examples of commodities, other than the extremely profitable opium, which could generate good farm-level profits and employment for women and men, if properly marketed, include:

- fruits and vegetables, including apples, pomegranates, lemons, excellent melons of various types, figs, tomatoes, and several types of legumes, including mungo beans. Potatoes sugar-beets and gourds (Sw. 'kalebass') may be more suitable for the domestic market 
- spices: saffron (very labour intensive, suitable for women) and black cumin are already being exported, sesame seeds have been grown for a long time

- medicinal herbs

- dried fruits, including raisins, apricots, dates and figs

- nuts, including walnuts, almonds and pistachios. Pistachios have a large and secure market in India.

- fragrances, e.g. rose oil

- flowers, both for the domestic market and exports

- olives have been grown in the area earlier and there is an unmet domestic demand for olives for medicine and cosmetics

- mulberry and silk production: FAO has arranged import of hybrid silk worm eggs in an effort to revive the traditional silk industry in northern and western Afghanistan.

In this context, The World Bank (2004) writes: "Fuelled by rising consumer incomes, international demand for income-elastic horticultural products is growing rapidly, notably in Russia, Eastern Europe, India and East Asia."

Post-harvest handling and marketing. The major challenge is post-harvest handling, including storage, processing and quality control, as well as marketing infrastructure. Christoplos writes: "Afghanistan has little chance of regaining a significant share in many of its former markets for dried fruit and other products without a considerable improvement in quality. Improved post-harvest handling and processing is essential."

Types of farms. According to a report from Kyoto University (Toderich \& Tsukatani, 2004) there are three types of farms in Kunduz: large scale private farms, a small number of collective farms, and household plots. Household plots generate a large share of livestock and vineyard, fruits, melon and gourd crops, potatoes and vegetables.

Mismanagement of irrigation systems. According to the same report, "mismanagement and negligible infrastructure of water irrigation systems in all surveyed areas have contributed to massive population displacement, increased opium production, conflicts over land and grazing and consequently breakdown of traditional socio-economic networks."

Current rehabilitation and development projects. According to UNAMA, there were 221 on-going interventions with international support in the agricultural sector in Kunduz in August 2004. Please refer to Appendix II.I Maps of Reconstruction and Development Projects in Kunduz, August 2004: Agriculture projects. The implementing agencies/NGOs were:

Food and Agriculture Organisation of the United Nations, FAO, 128 interventions International Centre for Agricultural Research in the Dry Areas, ICARDA, 45 interventions Mercy Corps International, MCI, 26 interventions

Kunduz Rehabilitation Agency, KRA, a local NGO, 15 interventions

Child Fund Afghanistan, CFA 5 interventions

Department of Agriculture, DoA, 3 interventions

Swedish Committee for Afghanistan, SCA, 2 interventions ( 3 according to SCA)

Irrigation projects. In addition, according to UNAMA, there were 33 on-going irrigation interventions with international support in August 2004. Please refer to Appendix II.7 Maps of Reconstruction and Development Projects in Kunduz, August 2004: Irrigation projects. 
The implementing agencies/NGOs were:

United Nations Office of Projects and Services, UNOPS, 8 interventions

German Agro Action, GAA, 8 interventions

Department of Rural Rehabilitation and Development,DoRRD, 7 interventions

World Food Programme, WFP, 4 interventions

International Organisation for Migration, IOM, 4 interventions

Kunduz Rehabilitation Agency, KRA, 1 intervention

Food for the Hungry International, FHI, (a Korean NGO), 1 interventions

The Swedish Committee for Afghanistan (SCA) is distributing wheat seeds and providing extension services to 4,220 contracted farmers in three districts: Kunduz, Imam Sahib and Khan Abad.

According to the Kyoto report quoted above, FAO has recently distributed some 1,500 tons of wheat seeds to some 30,000 families in northern Afghanistan. The first priorities of USAID and ICARDA are to restore critical farming activities, including landscape rehabilitation and seed recovery production. The Kunduz Experimental Agricultural Centre run by local and expatriate scientists, with the support of ICARDA, UNDP and FAO, are reintroducing traditional wheat, maize barley, chickpeas, lentils and other seeds improved through breeding to be more productive and disease tolerant.

WFP is shifting its programmes in the area from relief to rehabilitation. WFP will also organise a Food for Work project in Zangi village, Ali Abad District, where crops of more than 100 hectares of land were burnt by accidental fire during the harvesting season, affecting the lives of 30 families. (UNAMA Press Briefing, 12 September 2004)

The Aga Khan Foundation (AKF) is running the Afghanistan Rural Micro-Credit Programme (ARMP) with 377 clients in the Khan Abad and Char Dara districts. Many of the micro-credits are used for small agriculture and livestock projects. Funding is provided by the Microfinance Investment and Support Facility for Afghanistan (MISFA), a national programme under the supervision of the Ministry of Rural Rehabilitation and Development (MRRD) and the World Bank through its Consultative Group to Assist the Poor (CGAP). By November 2004, 57,000 active loans have been issued in Afghanistan through MISFA. Fifty-three percent of these loans have gone to women. MISFA has a target to reach 100,000 clients by March 2005

USAID/RAMP. In the summer of 2003, USAID started the three-year Rebuilding Agricultural Markets Programme (RAMP) aimed at increasing food security and incomes of rural people in thirteen provinces including Kunduz. The programme has two principal objectives: to increase agricultural productivity and output, and to facilitate effective networks between producers, processors and markets. The main activities to reach these objectives are:

- Expanding rural finance opportunities, e.g. microfinance loans (in cooperation with The World Bank), ranging between $\$ 50$ and $\$ 5,000$ to support small agricultural and women-owned businesses. By August 2004, some 2,000 loans have been disbursed.

- Improving rural infrastructure, e.g. rehabilitation of farm-to-market roads, irrigation canals and dams. At present (August 2004), RAMP is repairing 25 kilometres of farm-tomarkets roads in Kunduz, as well as constructing four water intakes which will provide 
water to more than 50,000 hectares of wheat, cotton and rice producing land. Also in Kunduz, dams are constructed at Isakhil and Bande Jadeed, and bridges are built at Alchin and Beshkupruk. Eight culverts are are built at Qanum, and flood protection is being arranged in several places.

- Generating improved agricultural technology, e.g. on-farm demonstration to illustrate the effectiveness of new crops, and improved irrigation and cultivation as well as postharvest techniques. Field demonstrations have included crops such as wheat, rice, onions, virus-free potatoes, peanuts, mungo beans, canola and tomatoes. Locust control activities in Kunduz have improved food security for a large number of families.

- Creating facilities to support markets, e.g. establishment of village collection centres, wholesale markets and village/district market centres.

- Developing the livestock industry, including veterinary services, advice on animal nutrition, disease control and livestock management. In Kunduz, women have been trained in poultry management as an income-generating activity. 


\section{PRIMARY AND SECONDARY EDUCATION}

"The potential contribution of a revitalised education system to the resolution of Afghanistan's many difficult problems is immense. Education is at the core of the long-term programme to rebuild Afghanistan, enabling progress in all other development arenas as well as facilitating national unity. While the challenges facing the education system are enormous, there is a prevailing atmosphere of excitement, expectation, and determination in schools and communities throughout the country."

Excerpt from A Guide to Government in

Afghanistan, AREU and The World Bank, 2004

Limited capacity and resources. However, the current education system has extremely limited capacity and resources such as teachers, textbooks, materials and buildings to produce good results. On all levels, qualified educators and managers are scarce. There is no technological communication system to connect the Ministry of Education and the provincial education departments.

Centralised system. The education system in Afghanistan is extremely centralised. Most key decisions are made in Kabul. This includes curriculum development, teacher training, approving recruitment of teachers and headmasters, selection and production of texts, and, especially, controlling financing and spending. Provincial and district offices have very limited decision-making authority. There are no community-managed schools, other than those sponsored by NGOs and donors.

Back-to-school campaign. The government's back-to-school campaign, jointly funded by USAID and UNICEF (strongly supported by Sida), resulted in more than 3 million children in school (grades 1-12) at the start of the 1381 school year (March 2002), up from an original estimate of 1.7 million. In September 2004, the US Embassy in Kabul announced that more than 4.8 million children are now enrolled in schools throughout the country, the largest number in the history of Afghanistan.

During the first phase of the campaign in Kunduz, distribution of learning materials to some 180,000 children and teaching materials to some 2,500 teachers was planned. However, this distribution was delayed.

Teachers' salaries. According to the Ministry of Education (June 2004), the average monthly salary for government teachers has been raised to 2,700 Afs in 2004. In addition, some teachers receive U.S.-supported food assistance as a salary supplement (10 litres of vegetable oil per month, in theory) through WFP and the Ministry of Education. Payment of salaries is often delayed by months. In some cases, teachers in NGO-supported school are receiving double salaries, from the government and from the NGO. (The SCA average monthly salary for teachers is only 1,900 Afs.) The salary grade level is largely determined by seniority (length of service) rather than merit. This means that headmasters or administrators might have a lower salary than some of the teachers they supervise. The salary system is likely to deter some bright young people from making a career in the education sector.

Teachers' level of education. For most teachers in Afghanistan, the level of education is very low. Few teachers have more than a grade 12 education. Some NGOs, including SCA, provide in-service training, but most teachers have had little or no formal teacher training. 
Teacher training. There is an enormous shortage of solid teacher training in Afghanistan. After UNICEF, SCA is one of the major providers of teacher training in the country. SCA offers four types of short in-service teacher training:

- subject knowledge, 2 months

- subject teaching competency, one month

- methodology, two weeks

- administrative training for headmasters, two weeks

Some 1,600 teachers and headmasters from all over Afghanistan are trained yearly by SCA. Of the trainees, 21 percent are women.

The BBC (British Broadcasting Corporation) produces educational radio programmes (via distance learning) and weekly teacher training radio programmes for Afghanistan.

Staff and gender. Data on government teachers are not available. As for the teachers on the SCA payroll in Kunduz, 65 percent of the teachers in primary school are male and 35 percent female. Of the secondary school teachers, 100 per cent are male.

Enrolment and gender. A survey by the Ministry of Education and UNICEF in 2002, found that approximately 50 percent of the students enrolled in 1381 (2002) were in grade one, due to the massive return of children, not least girls, after many years of conflict and closed schools. This resulted in large grade one classes of mixed age composition. Of all children enrolled, 92 percent attended primary school (grades 1 to 6 ) and only 8 percent secondary school (grades 7 to 12 ).

The same survey showed that, on the national level, 30 percent of the students enrolled in primary school in 1381 (2002) were girls; and out of the 73,000 teachers, 28 percent were female. Gender disparity varied a lot between provinces and within provinces. The highest level of gender equality in education was found in Kabul: 45 percent girl students and 65 percent female teachers. 41.8 percent girls in the SCA primary schools in Kunduz Province is a relatively high figure. The lowest level of gender equality was found in Uruzgan Province: only two percent of the students were girls, with no female teachers. (In 1999, the estimated national enrolment rate was 3 percent for girls and 38 percent for boys.)

According to UNICEF (2003), 57 percent of the school-aged boys (7-13 years) in Kunduz attended school that year. This was lower than the national average of 67 percent for boys. Only 36 percent of the school-aged girls in Kunduz (i.e. all primary schools, not only SCA schools) attended school. This was lower than the national average of 40 percent for girls.

NGOs play an important roll in primary and secondary education in Kunduz. See Appendix Il.3 Map of Education Projects in Kunduz in August 2004. According to UNAMA in Kunduz, the following NGOs and agencies were active in the education sector in August 2004:

CFA, Child Fund Afghanistan, 91 interventions

WFP, World Food Programme, 17 interventions

MCI, Mercy Corps International, 15 interventions

SCA, 12 interventions according to UNAMA, 17 interventions according to SCA

IOM, International Organisation for Migration, 12 interventions

BRAC, Bangladesh Rural Advancement Committee, 7 interventions

Caritas, 4 interventions 
FHI, Food for the Hungry International, Korea, 4 interventions

Katakhail (a local NGO, 4 interventions

UNOPS, UN Office for Project Services, 4 interventions

GTZ, Deutsche Gesellschaft für Technische Zusammenarbeit, 3 interventions

DED, Deutscher Entwicklungshilfe, 1 interventions

AKF, Aga Khan Foundation, 1 intervention

The Child Fund Afghanistan (CFA) is a branch of the Christian Children's Fund (CCF) (see below). CFA organises primary education for illiterate women and demobilised soldiers. In addition, CFA works with child protection and micro-credits for women. CFA works in all districts of Kunduz.

The Swedish Committee for Afghanistan (SCA) is supporting 17 primary schools in 7 districts in Kunduz Province. Of these schools, 4 are for boys only; 2 are for girls only; 4 are for boys, with girls in a separate annex; and 7 are mixed schools, with boys and girls in the same location. No home schools are included. The total enrolment is 14,977 students, of whom 41.8 percent are girls. In these schools, 65 percent of the teachers are male and 35 percent female. Dari is the language in 82.4 percent of the schools, Pashtu in 17.6 percent.

SCA is also supporting a secondary school (grades 7 to 12), in Kunduz District (Hazrat Sultan village), with a total enrolment of 195 students, all of whom are boys. All teachers (13) are male.

The Christian Children's Fund (CCF) has been rehabilitating old schools with UNHCR funds and building new schools with German funds in Kunduz. In addition, CCF is rehabilitating a teacher training school and a secondary school in Kunduz. CCF is also offering some 26,000 children and youth education in so-called Child Centred Spaces in Kunduz.

The World Food Programme (WFP) provides school feeding for children in 110 schools. Through the Food for Teachers programme, teachers $(5,000)$ in Kunduz get 9.25 litres of food oil per month. Cp. Teachers' salaries above. Through a Food for Work project, construction workers building schools are paid with food. In two districts, women participate daily in literacy classes arranged by the Department of Women's Affairs. Both the women and their teachers, in all 749 persons, receive food aid on a regular basis.

The Aga Khan Foundation (AKF) provides teacher training and ensures that overhead costs are covered for a newly rehabilitated and extended village school in Chesmai Sher village in Khan Abad district. GZT has financed the construction, and the German PRT has helped with transports. (South Asian Free Media Association, 30 August 2004)

For $2005, \mathrm{AKF}$ is planning to construct a school in the Nekpai cluster with Ismaili population. There is also a proposal for an education programme called the Story-tellers Project (Qesseguha) aiming to promote and preserve the cultural heritage of the programme area, and at the same time promoting pluralism and cultural exchange between the various ethnic groups who live there. AKF has approached Germany for funding. (Personal communication, AKF, November 2004)

USAID. In February 2003, USAID allocated $\$ 60$ million for a nation-wide three-year plan to renovate 1,000 schools, print textbooks and train teachers. Under the USAID Rehabilitation 
of Economic Facilities and Services (REFS) Project, three new primary schools will be built in Kunduz during 2004, at a cost of $\$ 175,000$ each. In addition, five primary schools and three secondary schools in Kunduz will be refurbished. The implementing agency is the International Organisation for Migration (IOM). Also, USAID is in the process of rebuilding two teacher training schools, one in Kabul and one in Kunduz.

The USAID official I interviewed in the American Embassy in Kabul regretted that he could not visit the project sites in Kunduz to evaluate the progress. The German ISAF team was not able to provide him with the required two escort teams of 'protective shooters', one in the front and one in the rear of his car, plus an ambulance with medical staff.

The Coalition Joint Task Force-180 (CJTF-180) has reconstructed a large number of schools, including the Majar Primary School $(\$ 75,000)$, the Lycee Astal Ghazee School in Kunduz City $(\$ 62,500)$, the Sujani Ulya School in the Char Dara District $(\$ 62,500)$ and the Lycee Zakheel School $(\$ 80,000)$.

Human Rights Research and Advocacy Consortium (HRRAC). In March 2004/Hamal 1383, at the start of the new school year, the Human Rights Research and Advocacy Consortium (HRRAC) released the publication Report Card: Progress on Compulsory Education. HRRAC concluded that although enrolment has increased a great deal, more than half of Afghanistan's children do not attend primary school. Less than 34 per cent of those enrolled are girls. Drop-out rates are high, especially among girls. The quality of education is low.

The World Bank. The first World Bank grant for education in 2002 amounted to $\$ 15$ million. The project was facilitated by CARE and BRAC in five provinces (Bamyan, Logar, Kapisa, Parwan and Badakhshan). Both of these NGOs were selected by the Ministry of Education on a competitive basis. The approach has been decentralisation, with school management committees including teachers and parents.

In July 2004, The World Bank/IDA granted $\$ 35$ million for the Education Quality Improvement Programme (EQUIP) Project in Afghanistan. EQUIP will build on the model of community involvement created with the help from the first grant. Since it is a national programme, Kunduz will also benefit from it. Investments will be made in "human resources (teachers, principals and educational administration personnel), physical facilities, promotion of school-based management and capacity building of provincial and district education departments. The project will also promote education for girls by emphasising the priority of female teachers and students in each component activity."

In September 2004, The World Bank announced that all provincial education offices will be provided with high frequency radio communication equipment to improve their school monitoring activities and their communications with the Ministry of Education in Kabul. 
"... the conditions for educational development in Afghanistan, especially in terms of improving quality, do not look promising. There is no shared vision of the problems and priorities facing the education sector. There appears to be no prominent champion of reform at either the national or provincial levels, and there is a remarkable degree of complacency with the status quo. The highly centralised administration of education does not encourage innovation, and tight expenditure controls at all levels almost dictate an inefficient use of scarce resources."

From A Guide to Government in Afghanistan, AREU and The World Bank, 2004

Recommendations. Some of the recommendations for the future in the publication quoted above are as follows:

- There is an urgent need to rebuild and modernise teacher education facilities, not least for female teachers, to support quality improvement.

- Community involvement and participation offer the best hope for sustained education improvements.

- Teachers' salaries have to be paid promptly and textbooks and other supplies have to be delivered in time.

- Expose senior educators to international experience of education reform.

- Build planning capacity in provincial and district offices. This has to be a top priority. 


\section{HEALTH}

Afghanistan's health indicators are among the worst in the world, with large gender gaps. According to The World Bank (2004), the under-five mortality rate is 172 , the infant mortality rate is 115 , and the estimated maternal mortality rate is 16 (all per 1,000 live births). The rate of chronic malnutrition (moderate or severe stunting) is around 50 percent. Disability rates due to polio, cerebral palsy, and conflict (including landmines) are very high. Almost half of all deaths among women of reproductive age are a result of pregnancy and childbirth.

It has been estimated that some 23,000 Afghan mothers die in childbirth every year, making it the country's leading cause of death for women. It has been characterised as a public health catastrophe with few parallels elsewhere in the world. (www.afgha.com, 30 May 2004)

Some girls are married as young as 12 (or even younger) and give birth at 13 , long before they are full-grown adults. Those who survive bear an average of seven children. Three out of four babies born to mothers who died, died themselves with in the first year. The government goal is that every province in the country will have at least one fully functioning emergency obstetrics care centre by the end of 2004 or early 2005. (UN News Centre, 3 March 2004)

UNFPA often points out that parents with fewer children can invest more in their nutrition, health and education. UNFPA also stresses that, to overcome poverty, governments must deal with population concerns and fight poor reproductive health, unwanted fertility, illiteracy and discrimination against women.

$\begin{array}{lccl}\begin{array}{l}\text { Safe motherhood } \\ \text { \% of mothers who did not give birth in a }\end{array} & \text { Kunduz } & \text { National } & \text { Ranking } \\ \begin{array}{l}\text { health facility } \\ \text { \% of mothers where last delivery was assisted }\end{array} & \mathbf{9 7 *} & 89 & 13 \\ \begin{array}{l}\text { by untrained health professional } \\ \text { \% of women who did not attend antenatal care }\end{array} & \mathbf{9 4} & 86 & 18 \\ \text { \% of women never heard of family planning } & \mathbf{7 4} & 84 & 10 \\ \text { \% of women currently not using family planning } & \mathbf{9 3} & 72 & 11 \\ & & & 10\end{array}$

Provincial report for Kunduz Province, UNICEF, 2003

* This means that only three percent of the births in Kunduz occur in health facilities.

The most common diseases and medical problems in Kunduz are as follows:

- high-risk pregnancies

- tuberculosis, typhoid, respiratory diseases

- malaria

- diarrhoea, worm infestations, and other infections

- accidents, injuries, burns

Records of cases of HIV/AIDS and other sexually transmitted illnesses are not kept. It is generally thought that the incidence of HIV/AIDS is still low. SCA has plans for 2005 to sensitise Afghan society towards the issue and to incorporate preventive activities into the ongoing programmes. (SCA Workplan \& Budget 2005-06, SCA, 2004)

Many, probably most, health problems could be avoided by basic health care education, good nutrition, vaccines and potable water. 
The official public health priorities in Afghanistan are:

- reduction in under-five mortality

- reduction in maternal mortality

- addressing malnutrition

- prevention and control of communicable diseases

- addressing inequitable distribution of health services

- capacity building

The Basic Package of Health Services (BPHS) was presented by the Afghan Ministry of Health in March 2003, as a result of cooperation between the Ministry and the major donors in the health sector (USAID, World Bank/IDA, EC and UNICEF), NGOs and UN agencies. It provides a standardised list of basic services, including maternal and newborn health, child health and immunisation, public nutrition, and communicable disease control, which should all form the core of primary health care facilities. BPHS is designed to promote redistribution of services in order to improve access and benefit the most under-served areas. Every province should have good hospital facilities for emergency obstetric care.

Since October 2003, SCA is the implementing partner of the Ministry of Health for the BPHS in Kunduz. A contract called the Performance-Based Partnership Agreement (PPA) was signed between SCA and the Ministry of Health. Funding for SCA health work in Kunduz is provided by the European Community (EC).

In Afghanistan, the total number of medical doctors is low. Other medical staff are even more scarce. Of all health workers, 24 percent are doctors. Of the doctors, less than a quarter are women. There is an urgent need for training of more mid-level health workers, especially women.

It is difficult to recruit staff to remote rural areas. In spite of top-ups and incentives, many rural health facilities are significantly under-staffed. In the case of women doctors and nurses, there are the additional needs for personal security and employment for the husband. Poor roads, poor public transport and communication facilities aggravate the problem. Vehicles and fuel are in desperately short supply.

NGOs and other agencies in the health sector. Afghanistan has more than 80 international NGOs and about 25 national NGOs working in the health sector. Eighty percent of the existing health facilities in Afghanistan are either operated or supported by NGOs. According to UNAMA in Kunduz, the following NGOs and other agencies were working in the health sector in Kunduz in August 2004 (see also Appendix II.5, Map: Health projects):

World Health Organisation (WHO), 31 interventions

Swedish Committee for Afghanistan (SCA), 26 interventions

Health Net International (HNI), 16 interventions

World Food Programme (WFP), 14 interventions

International Organisation for Migration (IOM), 4 interventions

UN Office for Project Services (UNOPS), 1 intervention

The Swedish Committee for Afghanistan (SCA). As the so-called Performance-Based Partner to the Ministry of Health in the implementation of the Basic Package of Health Services (BPHS) in Kunduz, funded by the European Community, SCA has agreed to build 
clinics, train doctors, midwives and nurses, improve nutritional standards, institute immunisation programmes, and purchase and distribute essential drugs.

SCA runs the Provincial Hospital in Kunduz City. The hospital, inaugurated in August 2004, has 100 beds, and is fully equipped for surgery, x-rays, blood bank, ECG, gynaecology and obstetrics. In 2005, a hospital with 50 beds will be opened by SCA in Imam Sahib. SCA is also responsible for the running of a total of 19 health clinics located in the seven districts of Kunduz.

In addition, SCA runs a midwife training centre in Kunduz, with funds from EC. In February 2004, SCA conducted some 35 focus group discussions on health with men, and interviewed 500 women through a questionnaire on knowledge, attitude and practice regarding health, and reproductive health in particular. One finding was that women were very interested to know about family planning and other aspects of reproductive health. The questionnaires and the results of the focus group discussions are now being processed. A report is expected at the end of 2004.

SCA is cooperating closely with Health Net International (HNI), a lead NGO in the WHO Roll Back Malaria (RBM) programme funded by the EU. The use of insecticide treated nets (ITN) in combination with health education messages form the core of the malaria prevention programme.

SCA is also cooperating with the Afghan Connection (AC), a British NGO, in the field of Paediatrics and Gynaecology/Obstetrics. The Afghan Connection is planning to link the Kunduz Hospital to British hospitals and to encourage training rotations in Kunduz. AC will also fund a resource centre for the medical staff and some further equipment for the hospital. The funding comes from The Sunday Times Appeal and individual donors.

The NOOR programme of the Kabul-based International Assistance Mission (IAM) operates a mobile eye clinic in Kunduz on a temporary basis. NOOR has operated almost continuously in Afghanistan since 1966. They provide almost all medical and surgical eye care in the country.

The World Health Organisation (WHO) has a sub-office in Kunduz, serving the northeastern region. WHO is cooperating with SCA in training of medical staff and the implementation of the IMCI (Integrated Management of Childhood Diseases) programme. In Kunduz, WHO is also active in campaigns against malaria, TB and polio, and distribution of essential drugs and emergency drugs.

The World Food Programme (WFP) provides food for institutional feeding, including TB patients, and children in orphanages.

UNICEF has provided vaccine for the Expanded Programme for Immunisation.

The European Commission (EC). The EC support for the health sector nationwide in 2004 is $€ 20$ million. This includes funding of BPHS in Kunduz, Uruzgan and Zabul, and most districts in Kunar, Laghman and Nangarhar.

USAID. USAID is funding a multi-million-dollar programme, called the Hopkins Programmme, to train 400 midwives in Afghanistan by 2006. At present, there are 467 trained 
midwives in the country. It is estimated that 18,000 midwives are needed. The SCA midwife training, funded by EC, in Kunduz is benefiting from this programme, e.g. by sharing curriculum and training materials.

Under the USAID Rehabilitation of Economic Facilities and Services (REFS) Project, 16 new health clinics (11 basic and 5 comprehensive) were built in Kunduz during 2003. The implementing NGO was Shelter for Life (SFL). During 2004, five health clinics will be refurbished. The sites will be selected by the Ministry of Health, and the implementing agency will be IOM (International Organisation for Migration). All clinics are built to be earthquake resistant.

The German Provincial Reconstruction Team (PRT) runs a small super-modern hospital, for emergency medical and surgical treatment, in Kunduz City. Afghan civilians needing expert care, especially for severe burns and surgery, are admitted as patients in the German PRT hospital. (SCA staff, November 2004) 


\title{
10. DISABILITY
}

"Households with disabled people are visibly among the poorest along a number of dimensions:
they have higher poverty rates and food gaps than average, and less land ownership and access
to irrigated land. There is also a higher incidence of female-headed households in this category.
However, by no means are all households with disabled people poor. Depending upon the
severity of the disability, how this impacts on both the individual as well as the household as a
larger entity, the activities of non-disabled household members, and existing household assets
including social capital, there is considerable variation in household wellbeing."
From "Afghanistan: State Building, Sustaining Growth, and
Reducing Poverty. A Country Economic Report," The World
Bank, 2004

\begin{abstract}
"Recent local surveys indicate that about $3.5 \%$ of the population of Afghanistan is disabled... While people disabled by war form a highly visible proportion of the disabled population, an equally significant but much less visible group are those with sensory and multiple impairments. Many disabled people are hidden from view, especially women and children, trapped by their culture and lack of services within the very narrow confines of their homes.
\end{abstract}

Although the political, social and economic situation in Afghanistan is improving after 24 years of war, many factors and causes of disability remain the same. Mines, cluster bombs and other unexploded ordinance continue to kill and maim people, as do the sporadic acts of warfare that continue in the country. The new emerging health system has not yet been able to reduce, to any substantial degree, the prevalence of disabling diseases such as polio and tuberculosis, nor to provide women in reproduction with adequate service to prevent birth complications such as cerebral palsy. Nor has it addressed disability in its Basic Package of Health Service. A high rate of intermarriage results in increased number of children with malformations and disabling disorders, both physical and mental. A wareness about risks that can be avoided, such as dangerous environment, improved quality of traffic behaviour and performance, remains low, and so does the literacy and educational level, further perpetuating adverse and disability-prone life styles. Concepts such as equal opportunities for people with disability are not widely spread and the prejudice against them is great. People with disability are not integrated in the mainstream services; they are rather actively excluded. They belong to the most oppressed, exposed and vulnerable segments of the population."

From "Workplan \& Budget 2005-06", Swedish Committee for A fghanistan, October 2004

In early 2003, a draft national disability policy document was presented by the concerned NGOs and the Ministry of Martyrs and Disabled. This policy document, however, has not been endorsed by the government.

In September 2004, UNDP organised a one-day meeting on the Comprehensive Disabled Afghans Programme (CDAP). Progress achieved and challenges for the future were discussed. In the field of physiotherapy, a task force was formed under the leadership of UNDP to work on curriculum development, possibly extending the training from two-three years to four years.

In Kunduz, there is a high incidence of disabilities. Kunduz was a war zone for many years, and this has resulted in many mine-blast and war victims. There are also many cases of disability related to polio and cerebral palsy.

The Swedish Committee for Afghanistan (SCA) is the only organisation providing services for the disabled in Kunduz Province on a permanent basis, according to UNDP (October 2004). This work is funded by Sida. SCA's assistance, named Rehabilitation of Afghans with Disability (RAD), includes Physiotherapy Centres (for men and women separately), 
Community Rehabilitation Centres, village libraries and Disabled Persons' Organisations (DPO) in two districts, namely Kunduz and Khan Abad. Special education for the visually and/or hearing impaired and the mentally retarded is also provided. Adult disabled persons are offered vocational training and micro-credits. In addition, community-based rehabilitation (CBR) in the homes of the disabled is also offered.

For information on temporary services for the disabled in Kunduz, see Chapter 9. Health, above.

The Ministry of Martyrs and Disabled provides some welfare payment to the disabled.

The German PRT in Kunduz has plans to establish a small orthopaedic workshop in Khan Abad. (UNDP, October 2004)

There is a great need for more support to the disabled in Kunduz Province, especially in districts where no services are available at present.

Postscript. On 2 December 2004, the UN News Centre in Kabul announced that a comprehensive disability strategy for three years, with a foreseen national budget of US $\$ 9.4$ million, had been agreed in late November, and will be signed once the new Afghan government is in place. 


\section{APPENDIX I}

Monday, 17 May 2004

\section{Terms of Reference:}

\section{The mission is to produce a "Province Analysis" (province survey) of Kunduz and Wardak respectively.}

The province surveys shall describe problems and resources in the provinces, focusing on socio-economic conditions and demography, as well as factors that are relevant for our programmes (health, education, disabled, and agriculture).

SCA's policy is emphasizing poverty reduction and gender as being issues of great importance. Perspectives on these factors should therefore also be elucidated.

Basic information about drug handling and the warlords' positions shall be included, as well as an outline of the leading political actors and relevant structures (political, social, religious).

The surveys shall reflect existing and possible future actors of importance for development and reconstruction, and indicate a forecast of future commitments.

Target groups for the subsequent study of the report that is outline summaries of findings are those who are monitoring and developing SCA:s commitments in the SCA project (Basic Package of Health Service) of Kunduz and Wardak, Senior management staff at The Kabul Management Office and the SCA board.

Working period is $2 \times 4$ weeks of full time work including a period (not surpassing two weeks) in Afghanistan.

The province surveys shall be delivered to SCA not later than October 15, 2004.

A preliminary report shall be given to the Secretary General of SCA one month in advance in order to give the SCA staff possibility to provide feed-back on the semi-final products. 


\section{REFERENCES}

\section{APPENDIX III}

Afghanistan Research and Evaluation Unit (AREU) and The World Bank. A Guide to Government in Afghanistan. Kabul: AREU and The World Bank. 2004.

Afghanistan Research and Evaluation Unit (AREU) and The World Bank. Subnational Administration in Afghanistan: Assessment and Recommendations for Action. Kabul: AREU and The World Bank. 2004.

Amnesty International. Out of sight, out of mind: The fate of the Afghan returnees. Amnesty International. 2003.

Amnesty International. 'No one listens to us and no one treats us as human beings': Justice denied to women. Amnesty International. 2003

Baltimore Sun. "Birth shadowed by death." 30 May 2004.

Bryer, J. Working for Afghanistan: The Impact of Non-Governmental Organisations. BAAG. 2004.

Christoplos, I. Out of Step? Agricultural Policy and Afghan Livelihoods. Kabul: AREU. 2004.

CIA. CIA - The World Fact Book 2004. CIA. 2004.

Constable, P. "Project Put Strain On Afghan Province: Disarmament and Poppy Eradication Leave Residents Feeling Persecuted." Washington Post. 24 May 2004

Dagens Nyheter. "Amnesty-oro för återvändande afghaner.” 21 April 2003.

Gannon, K. “Afghanistan Unbound.” Foreign Affairs. May/June 2004.

Giustozzi, A. Respectable Warlords? The Politics of State-Building in Post-Tale ban Afghanistan. Development Research Centre, LSE. 2003.

Giustozzi, A. 'Good' State vs. 'Bad' Warlords? A Critique of State-Building Strategies in Afghanistan. Development Research Centre, LSE. 2004.

Grace, J. Gender Roles in Agriculture: Case studies in five villages in northern Afghanistan. Kabul: AREU. 2004.

Human Rights Watch (HRW). The Rule of the Gun: Human Rights Abuses and Political Repression in the Run-up to Afghanistan's Presidential Election. HRW. September 2004.

International Crisis Group (ICG). Afghanistan: The Problem of Pashtun Alienation. ICG Asia Report No.62. Kabul/Brussels: ICG. 2003.

Ministry of Rehabilitation and Rural Development (MRRD). National Risk and Vulnerability Assessment 2004. Kabul: MRRD. 2004. 
Swedish Committee for Afghanistan (SCA). Workplan \& Budget 2005-06. SCA: Kabul/ Stockholm. October 2004.

Toderich, K. \& Tsukatani, T. A survey of land, vegetation and irrigation systems in North Afghanistan and neighboring Tajikistan. Kyoto Institute of Economic Research, Kyoto University. 2004.

UNHCR. District Profile. Various districts. UNHCR. 2002.

UNICEF. Various information sheets. Kabul: UNICEF. 2003-04.

United Nations Population Fund (UNFPA). State of the World Population 2002. People, Poverty and Possibilities: Making Development Work for the Poor. UNFPA. 2002.

United Nations Office on Drugs and Crime (UNODC)/GOA. Afghanistan Farmers' Intentions Survey 2003/2004. Kabul: UNODC/GOA. 2004.

USAID. "USAID Afghanistan." Various information sheets. Kabul. 2004.

World Bank. Afghanistan: State Building, Sustaining Growth, and Reducing Poverty. A Country Economic Report. The World Bank. 2004

Zia-Zarifi, S. "Losing the Peace in Afghanistan." Human Rights Watch World Report 2004. 


\section{APPENDIX IV}

\section{LIST OF CONTACTS FOR THE KUNDUZ SURVEY IN 2004}

\section{ACBAR \\ AIMS \\ AKF \\ ANSO \\ AREU \\ ARIC \\ BAAG \\ CARE \\ CND \\ CSO \\ EC \\ IOM}

LSE

Ministry of Health

President's Office

Radio Zohra

SCA

Sida

UNAMA

UNDP

UNHCR

UNICEF

USAID
Ms Anja de Beer, Executive Coordinator, Kabul

Mr Mohammad Hashim Mayar, Programme Coordinator, Kabul

Mr Abdul Wali Ahadi, GIS Specialist, Kabul

Ms Hasiba Jalali, Customer Services Assistant, Kabul

Ms Joanne Trotter, Senior Programme Officer, London

Mr Nick Downie, Programme Coordinator, Kabul

Mr Aftab Opel, Research Manager, Kabul

Mr Sayed Padshafi, Catalogue Officer and Assistant Area

Manager, Kabul

Ms Elizabeth Winter, Special Adviser, London

Mr Paul Barker, Country Director, Kabul

Ms Pauline Fowlie, Programme Officer, Kabul

Mr Ikramuddin Sarwary, Head of Public Relations, Kabul

Mr Mohammad Ali Watanyar, Director General, CSO, Kabul

Mr Mohammad Sami Nabi, President of Census and Surveys

Department, Kabul

Ms Elisabeth Rousset, Programme Officer, Kabul

Ms Tristan Burnett, Programme Manager, Kabul

Ms Karoline Lund, Programme Officer, Mazar-e-Sharif

Dr Antonio Giustozzi, Researcher, London/Kabul

H.E. Dr Suhaila Siddiq, Minister of Health, Kabul

Dr Feruzuddin Feroz, Deputy Minister of Health, Kabul

Dr Abdullah Sherzai, Deputy Minister of Health, Kabul

H.E. Hedayat Amin Arsala, Vice President, Kabul

Ms Najia Khudayar, Director, Kunduz

A group of women reporters at Radio Zohra, Kunduz

Many staff members, including

Mr Borje Almqvist, Journalist, Kabul

Ms Kerstin Bjork, MCH Trainer, Kunduz

Mr Jesper Jensen, Country Director, Kabul

Dr Ahmad Kashmiry, Health Coordinator, Kunduz

Dr Bengt Kristiansson, Secretary General, Stockholm/Kabul

Mr Asadullah Siyall, Administrative Manager, Kunduz

Ms Karin Seydlitz, Programme Officer, Stockholm

Mr Sergiy Illarionov, Head of Office, Kunduz

Mr Abdul Bashir, National Officer, Kunduz

Ms Sarah Dyer, CDAP Coordinator, Kabul

Mr Razi Khan Hamdard, CDAP National Officer, Kabul

Ms Anna Bendall, Regional Operational Information Coordinator,

Kabul

Mr Daniel Endres, Deputy Chief of Mission, Kabul

Ms Nooria Sadaat, National Officer, Kabul

Mr Sardarwali Wardak, National Officer, Kabul

Ms Nadia Behboodi, Assistant Project Officer

Mr Jonathan' Mark Cauldwell, Project Officer

Mr Robert Jimenez, Project Implementation Officer 
WFP

WHO

World Bank
Mr Gulbuddin Rashid, Field Officer, Kunduz

Dr Ahmed Shadoul, Child Health Promotion (IMCI), Kabul

Mr Asger Christensen, Senior Operations Officer, Kabul

Ms Carol Le Duc, Senior Social Development Specialist (Gender), Kabul

Mr Tashi Tenzing, Senior Sanitary/Environmental Engineer, Kathmandu/Kabul 